Portland State University

PDXScholar

1978

\title{
An explorative study of parents' ability to predict representative feelings of their children
}

Kathleen Marie Koudele

Portland State University

Follow this and additional works at: https://pdxscholar.library.pdx.edu/open_access_etds

Part of the Psychology Commons, and the Social Work Commons Let us know how access to this document benefits you.

\section{Recommended Citation}

Koudele, Kathleen Marie, "An explorative study of parents' ability to predict representative feelings of their children" (1978). Dissertations and Theses. Paper 2801.

https://doi.org/10.15760/etd. 2797

This Thesis is brought to you for free and open access. It has been accepted for inclusion in Dissertations and Theses by an authorized administrator of PDXScholar. Please contact us if we can make this document more accessible: pdxscholar@pdx.edu. 
AN EXPLORATIVE STUDY OF PARENTS' ABILITY TO

PREDICT REPRESENTATIVE FEELINGS OF THEIR CHILDREN

$$
\text { by }
$$

KATHLEEN MARIE KOUDELE

A report submitted in partial fulfillment of the requirements for the degree of

MASTER OF SOCIAL WORK

Portland State University

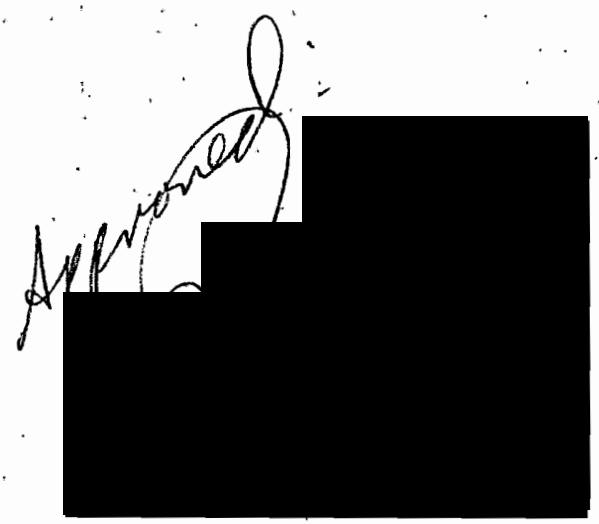

1978 


\section{ACKNOWLEDGEMENTS}

There are many to whom I wish to extend my thanks for their assistance in the completion of this study. I am especially grateful for my husband, Fred, and our children, Page, Dawn, and Lance. Their patience, understanding, and encouragement was always supportive. Special appreciation and thanks also go to my faculty research advisor who helped to make all my efforts a real learning experience for me. Finally, I wish to thank the children and parents who took their time to participate in this undertaking. I have learned a good deal from a11 of them. 
TABLE OF CONTENTS

PAGE

ACKNOWLEDGMENTS .

\section{CHAPTER}

I INTRODUCTION AND REVIEW OF THE LITERATURE. $\quad . \quad: \quad: \quad . \quad 1$

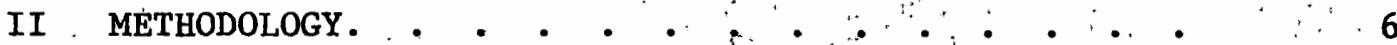

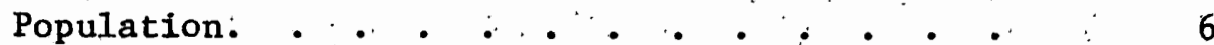

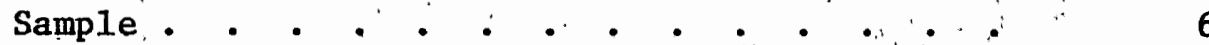

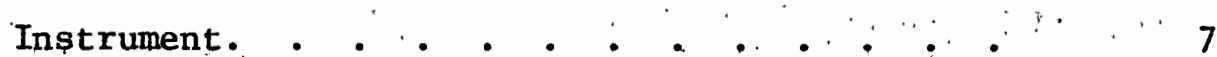

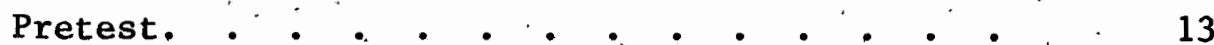

Data Collection .. : . • .

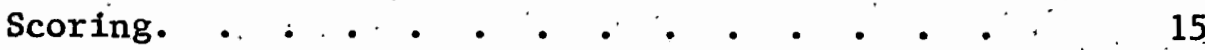

III ANALYSIS OF DATA • •

Quantitative • • . • . • . • • • . . 17

Qualitative . . . . . . . . • • . . 22

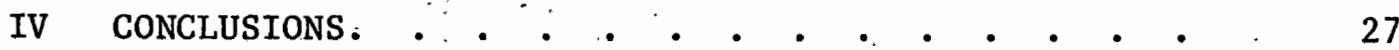

Summary. • • . • • . . . . • • • . 30

REFERENCES CITED • • • • • • • • • • • • • • • •

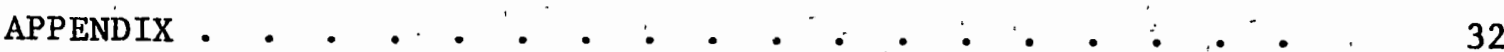

Appendix A: Children's Schedule . . . . . 32

Appendix B: Parențs 'Schedule . . . . . . 39

Appendix C: Pictures Accompanying Schedule . 46 


\section{CHAPTER I}

\section{INTRODUCTION AND REVIEW OF THE LITERATURE}

This is a study of thirty fifth-grade children and their parents to examine how accurately parents can predict the feeling reactions of their children in various situations." This focus on parent-child interactions regarding feelings has several implications for the field of Social Work.

Social Work is concerned with people's problems in living. Many problems of living are a result of poor communication with other people. Part of this problem in communication is the great difficulty many. people have of being aware of and expressing their feelings. Soctal. Work is also concerned with early intervention in problems as a way of helping prevent more serious problems from developing. 'It would.seem important then for social workers to be aware of the factors present in the early development of the repression of feelings, and the steps that can be taken to intervene in this problem.

The purpose of this study was to look at one possible factor in the early development of repression of feelings and poor communication patterns. From personal experience and observations it seemed apparent to this writer, that many parents fail to encourage children to express their feelings, but often assume that they. know what their children feel in different experiences and that parent actions are often based on these assumptions of their children's feelings. Sometimes parents not only do not encourage, but often discourage their children from 
expressing their feelings. Again, it is this writer's opinion that such actions by parents are based on the assumption that they think that they already know what their child is feeling. Such actions by parents may be one factor which aids in the development of repression of feelings in children. This factor could be influential whether the parent judgements or predictions were correct or incorrect. If the parents' predictions are incorrect; besides aiding the development of repression, the development of misunderstandings and poor communication patterns could be fostered. It seems worthwhile then, to determine whether parents are indeed able to predict the feelings of their children, as well as increase an awareness in parents of the possible problems such actions may promote.

The field of Social Work has long been aware of the importance of the family and parents on the emotional development of the child. Even though the role of the family has changed over the years, the family ". - is expected in our society, to be the locus of emotional expression and emotional support for adults as well as children."(Leichter and Mitche11, 1967, p. 284) Meyer emphasizes the need for Social. Work to be concerned with this task of the family:

Family life functions have changed in the urbanized society; family life may not have broken down as much as it may have taken on a highly specialized burden of providing an arena for affection and intimacy. This requirement for all individuals must surely be of major concern to social institutions that seek to promote individuality for all people. (Meyer, 1973, p. 76).

How then do families and parents learn to provide this specialized arena for emotional development?. Much is written for parent education of their children, yet Kessler states: 
- . a common omission in the education of the young child. . while parents usually encourage the child to learn the names of objects and answer his spoken or unspoken questions about the things he sees and hears, they do not usually teach him to express his inner feelings. (Kessler, 1966, p. 30)

Satir indicates a possible consequence of not being able to express these inner feelings:

Living in a family provides all kinds of seeing and hearing experiences. Some of these bring joy to the heart, some pain, and perhaps some bring a feeling of shame. Whatever feelings are aroused, if family members cannot recognize them and comment on them, the feelings can go underground and gnaw away at the roots of the family well-being. (Satir, 1972, p. 99)

Satir goes on to say that not. only can some families not recognize and comment on feelings, particularly negative feelings, but that many families have rules which prohibit discussion. "If your rules permit questions, you can ask me and then understand. If your rules don't permit questions, you can guess, and maybe make a wrong guess." (Satir, 1972, p. 102) Such a system of rules may account for the reason some parents guess about their children's feelings. Other factors may play a part in parents' encouraging the repression of feelings of their children. "Some of the parents' difficulty in recognizing and naming the emotions of their young harks back to their own childhood. This is particularly true of aggression. Many parents prefer to maintain an illusion of innocence, by denying any meanness." (Kessler, 1966, p. 31) Such comments, and many others of a similar nature, indicate to this writer that if Social Work is truly interested in primary prevention, one area that needs much more study would be parent-child interaction in the expression of feelings. Thus this study was designed to explore whether parents can successfully predict the feelings of their children. Such feelings would be those which would be elicited as a 
response or reaction to an experience or situation.

A request to the National Institute of Mental Health and the National Clearinghouse for Mental Health Information was made for a search of the literature on the subject of parents' ability to predict the feelings of their children. Among the more than six hundred items in the computer printout in their reply of May, 1977, not one dealt specifically with parents' perceptions of their children's reactive feelings. Several studies of a similar nature have been done on parents' perceptions of their children's feelings of themselves, or self-concept, such as that by Bledsow (1973), where parents' perceptions of their adolescent children were compared to perceptions of the adolescents about themselves. Bledsow found that parents perceive their adolescents more favorably than adolescents perceive themselves, and that mothers and fathers agree in their perceptions of their children. Piers conducted a study of parent prediction of children's selfconcepts using the Plers-Harris Children's Self-Concept Scale to assess the feelings of children about themselves. (Piers, 1972) Piers used two groups of children and parents; one a group of children brought to a clinic and one a group of normal children. Findings showed that parents of normal children overestimated and parents of clinic children underestimated their child's reported self-esteem. Another study by Langford and Alm investigated parental understanding of child feelings in the areas of self-adjustment and social adjustment. (Langford and A1m, 1954) This study also showed a difference in parents' perceptions of their children and the children's perceptions of themselves. The data showed that parents underestimated child feelings and concepts concerning self-adjustment, and over-estimated the feelings and ideas 
of the child concerning social adjustment.

These studies, as well as many others of a similar nature, have dealt with children feelings about themselves and their parents' perceptions of such feelings of self-image, self-concept and personality. They did not concern children's reactive expressions of emotions or feelings in different situations. Because these studies were focused on different types of feelings from those examined in this study, comparisons of findings are difficult to make. Such studies do indicate that parents' perceptions of their children differ in varying degrees from the stated perceptions of the children themselves.

Additional search of the literature using standard sources in the mental health field such as Psychological Abstracts, Sociological Abstracts, Abstracts for Social Workers; Social Sciences Citation Index, International Bibliography of Research in Marriage and the Family, and Comprehensive Dissertation Index, revealed nothing specifically related to the area of parents' perceptions of their children's reactive feelings. 
CHAPTER II

METHODOLOGY

In order to ascertain whether parents can predict the feelings of their children a study was designed whereby children could respond to an account of different experiences with what they were feeling. Parents could respond to the same accounts, answering as they thought their children would answer.

\section{Population}

Any inferences beyond the sample would be tenuous. The sample might be one time sample of the fifth grade pupils and their parents, with the traits noted later with respect to age, education, sex, ordinal placement and number of children. As in most Social Work reșearch, much replication is needed in highly: variable situations before warranted conclusions can be drawn.

\section{$\underline{\text { Sample }}$}

A non-random sample of thirty fifth grade students and their parents was used for the study. These students were mostly from one classroom of a school in a small rural town of about 1000 population. The parents of these children were basically we11-educated, all being high school graduates and many having some degree of college education. The parents have repeatedly stated their interest and shown their concern in their children. School teachers have also commented on degree 
of parent interest. There was no.single-parent family used in the study, nor any family with only one child. The parents of students in the classroom were asked via a telephone conversation if they would be willing to take part in the study. A few parents were not willing, and other fifth grade students from other schools in the same school district were included in order to obtain a sample of thirty students. Fifth grade students were selected chiefly because their reading skills and vocabulary would be fairly well developed, and the pre-adolescent age of older children could be avoided by selecting ten-year-old children. The rapid phystcal and emotional developmental changes that accompany the early adolescent period and the unevenness of such changes would likely add to the difficulty of parents' perceptions of their child.

\section{Instrument}

Since no previous study could be found with similar objectives to this writer's proposal, it was necessary to draft. a schedule. Such an undertaking was a major part of the study.

Study of projective techniques indicated that both stories and pictures were effective in eliciting feeling responses from subjects. Frank states:

- - every projective method may stimulate some emotional reaction or elicit a chronic affective reaction, as it evokes the individual's persistent patterns of action, speech, and thinking. . . The response to stories told by the clinician, particularly stories prepared especially to elicit emotional or affective reactions, also offers projective materials for understanding the individual personality. (Frank, 1948, p. 59)

Bell (1948) indicates that the use of pictures as a projective technique 
is effective for many situations. One use was with delinquents and it was found that pictures were". . of value in the psychiatric interview in prompting reactions from the uncommunicative, dul1, and distractible delinquent." (Be11, 1948, p. 254) It was hoped, by this writer, that if pictures were helpful in eliciting responses in delinquents, pictures would also be helpful in eliciting responses from normal ten-year-old children.

In order to prepare a schedule, other projective psychological tests of children were examined for situations and experiences that were meaningful to this age group. Buros test of Tasks for Emotional. Development, as well as the California Behavior Preference Manual listed many situations of concern for this age group. The Travis Projective Pictures (1957) uses". - scenes which are potentially conflictual, such as eating, sleeping, playing with dirt, sibling rivalry, punishment by a parent, jealousy of a parent, and aggression against parents." (Kessler, 1966, p. 81)

From tests such as these, situations were chosen for the schedule which included: peer socialization, attitudes for learning, acceptance of siblings, responsibility, respect for property of others, trying new things, fears of hospitalization, reciting at school.

From these kinds of situations short written vignettes were developed, each attempting to describe a situation in such a way that a feeling response could be elicited from the children. At the end of each vignette the child was asked to pretend that he/she was the person in the story. He/she was then asked, "What are you feeling?" A copy of the schedule is included in the appendix.

In order to assist the children in mentally visualizing the 
situation, magazine pictures in color were found to fit the vignettes. These pictures were chosen with care so that the subjects would not respond as to what they thought the child in the picture felt. The pictures often showed a child from the back; or with a nondescript facial expression. Some pictures were of others described in the vignette, not of the one whose feelings were being ascertained. Coples of the pictures used are included in the appendix. The pictures were mounted on colorful construction paper so that there was visual appea1. Knowing that subjects frequently expérlence anxiety in participating in a study in which they feel they are being tested, it was hoped that the appearance of colorful pictures would lessen the anxiety of the children and contribute to a more enjoyable feeling. More of the vignettes and pictures depicted negative situations than positive situations.

No names were placed on the schedules, but each child's responses were linked with his/her parents' responses by a coded number.

For statistical analysis of the study it was decided not to leave the question, "What are you feeling?" openended. A Iist of representative feelings was compiled that tried to encompass a wide selection of feelings using words that were familiar to fifth graders. At the same time an attempt was made to keep the list from being excessive in length to enable both children and parents to find quickly and easily a word that described their feelings. The list of feelings was separated into two columns, with those feelings which were generally positive in tone in the left column, and those which were generally negative in tone in the right column. Throughout the remainder of this report the word "tone" will be used to reflect the general positive or negative 
nature of the feelings.

The order of each list of feelings was determined by random selection, differing for each page of the five-page schedule. Eighteen words were used in the list of feelings, eight being generally positive in tone, and ten being generally negative in tone. Children and parents were instructed to answer each question by selecting one word from the list of feelings that came closest to describing their feelings.

The feelings listed in the schedule were as follows:

LIST OF FEELINGS

Helpful

Proud

Strong or Determined

Loving or Caring

Peaceful

Hopeful

Excited

Happy
Mean

Jealous

Guilty

Sad

Helpless or Weak

Hopeless or Discouraged

Bored

Angry

Humiliated or Shamed

Scared

Questions were placed in the schedule so that there was a mixture of positive-type experiences and negative ones; a mixture of those dealing with parents and siblings, with the initial question related to a positive and unthreatening situation. Two sample questions of generally happy occasions preceded the main schedule and followed 
the instructions. There were twenty questions to the schedule, nineteen of which were used for data analysis. The final question was to ascertain what the children felt after taking part in the study as an index of co-operation.

The schedule was designed so that when parent's response to a question was the same as that of the child, they were said to be in agreement or that the parent was successful in predicting the feeling of the child. The schedule was then able to provide data to examine the following hypotheses:

1. There is a significant difference in the responses of feelings expressed by childrẹn and the predicted responses of those children by their parents.

$$
\begin{array}{ll}
\mathrm{H}_{1}: A \neq B & A=\text { responses of children } \\
\mathrm{H}_{0}: A=B & B=\text { responses of parents }
\end{array}
$$

2. Mothers are able to predict their children's responses to a greater degree than are fathers.

$$
\begin{array}{lll}
\mathrm{H}_{2}: & \mathrm{B}_{1}>\mathrm{B}_{2} & \mathrm{~B}=\text { mothers' successful responses } \\
\mathrm{H}_{0}: & \mathrm{B}_{1}=\mathrm{B}_{2} & \mathrm{~B}=\text { fathers' successful responses }
\end{array}
$$

3. The degree of success in predicting responses is greater for parents predicting daughters than for parents predicting sons.

$$
\begin{aligned}
& \mathrm{H}_{3}: \quad \mathrm{B}_{\mathrm{A} 1}>\mathrm{B}_{\mathrm{A} 2} \quad{ }_{\mathrm{A} 1}=\begin{array}{l}
\text { success, responses of parents } \\
\text { of daughters }
\end{array} \\
& \mathrm{H}_{\mathrm{O}}:{ }_{\mathrm{A} 1}^{\mathrm{B}}={ }_{\mathrm{A} 2} \quad \mathrm{~B}_{\mathrm{A} 2}=\underset{\text { of sons }}{\text { success, responses of parents }}
\end{aligned}
$$

Dependent variables were:

- the number of responses of children and their parents in agreement.

- the number of responses of girls and their parents in agreement.

- the number of responses of boys and their parents in agreement. 
- the number of responses of children and their mothers in agreement.

- the number of responses of children and their fathers in agreement. Identification data on the schedule were collected for the following independent variables:

- sex of children.

- number of siblings.

- ordinal placement of child in family.

- age of parents.

- educational level of parents.

Although there was no attempt to control some of the intervening variables such as prior knowledge of the investigator, awareness of feelings in general, and degree of interest in the study, efforts were made to control the following:

- degree of stress encountered by the subject.

- the physical location of testing.

- reading ability of child subjects.

- length of attention span.

- subject's desire to present a good image.

Both children and parents were reassured several times before completing the schedule that it was not a test, and that there were no "right" answers. A similar statement was repeated in the written instructions. This writer talked briefly with the children as a group in their school classroom, explaining the nature of the study and that contact would be made with their parents about it. Several times it was stressed that it would be a fun thing to do. Because of the differing reading abilities of fifth graders, the investigator read aloud the entire schedule with the children, while they read along silently. After 
each question, "What are you feeling?" children silently selected one word from the List of Feelings and wrote that word in the appropriate blank on the schedule. They indicated that they were ready for the next question by turning the page in the book of pictures to the next picture. Children were encouraged to take their time in responding, and to respond as they honestly felt, not as they thought they should feel. The investigator seated herself so that she could not see how the children responded, and the children were reassured several times that their responses would remain anonymous and not be seen by their parents.

\section{Pretest}

A pretest of the schedule was given to six fourth and fifth grade students and ten of their parents. The data from these students and parents was not included in the analysis of the actual study. Prior to the pretest there were twenty-four questions on the schedule. This number was reduced to nineteen in order to shorten the length of time necessary to complete the schedule. Comments from the subjects of the pretest showed that two of the questions that were later omitted, were not easily understood by both children and parents. Two changes were also made on the List of Feelings based on subjects' comments. The word "Contented" was changed to "Peaceful," and the word "Anxious" was omitted due to several different interpretations.

When the investigator spoke to the fifth grade students in their classroom prior to the administration of the schedule, those students who had taken part in the pretest commented that doing so was fun. It was hoped that such comments lessened any anxiety the children may have been experiencing. 


\section{Data Collection}

When the schedule and pretest were completed, appointments were made with the parents of the fifth grade students after discussing the nature of the study, the length. of time involved and the anonymity of responses. At the scheduled time the investigator went to the home of the subjects.

The child was given the schedule to complete first. The time required for this varied from about fifteen to twenty-five minutes, with most children taking between fifteen and twenty minutes.' Parents of the children were asked for privacy for the child and investigator and in most instances the schedule was completed at the kitchen table. With prior permission of the parents, each child was given a candy bar upon completion of the schedule.

Following the children, the parents were asked to complete the schedule which in most instances they did simultaneously, sharing the one set of pictures for the schedules, having been instructed not to discuss their responses until they were both finished. The parents' schedule was different than the childrens' in that their instructions were written with emphasis for the parents to respond to each situation as they thought their child would respond. In addition, at the top of each page of the schedule were the words, RESPOND AS YOU THINK YOUR CHILD WOULD RESPOND. The investigator did not read aloud the schedule to the parents.

In a few instances when it was difficult to arrange for both parents to be home at the same time, a schedule and the pictures were left in the home for the absent parent to complete at a later time, 
again with instructions not to discuss the schedule with spouse or child until after its completion. The time required for parents to complete the schedule varied from twenty to thirty minutes. A copy of the schedule as given to the parents is included in the appendix.

It was recognized from the pretest that it would sometimes be difficult for parents to select the exact feeling chosen by their child to each question when there were eighteen from which to choose. What did seem to be of special Interest was the number of times that parents chose a feeling that was directly opposite in tone to that which was chosen by the child.

\section{Scoring}

In order to examine this factor, tabulation of results and scoring was done in the following way. Parents' schedules were compared to that of their child: Each question was scored "Agree" if the feeling listed by the parent was the same as reported by the child, "Disagree" if the parent responded with a different feeling, but still agreed with the same tone as stated by the child, and "Opposite" if the feeling chosen by the parent was of an opposite feeling tone to that reported by the child. Thus, if a child responded "sad" and the parent responded "angry" the question was scored "Disagree" as the feelings reported were not the same, but both responses were generally negative in tone. If the child responded "sad", and the parent responded "happy" the question was scored "Opposite" as the feeling tone was not the same.

Each parent's schedule was scored as to the total number of Agree, Disagree, and Opposite scores, with equal weight given to all questions. Results were compiled on a tabulation sheet with both father's and 
mother's score to each question, as well as total scores for the entire schedule. Also on the tabulation sheet were listed the other independent variables. The children's responses to each question were also tabulated with the number of times each feeling was used as a response to each question.

Study data was analyzed by quantitative as well as qualitative means. For quantitative analysis percentage figures were used for descriptive purposes. Chi square examination was used for drawing inferences and testing of hypotheses because of the nominal data. It provided a test of significant difference where appropriate. Criteria of significance was the .05 level. Qualitative analysis of the data included subjective observations by the investigator as well as comments of the parents on areas of special concern.

While there was not a random sample, these test's were used for purposes of later studies where randomization might be used. To the extent that the sample was representative over time, statistical techniques are probably valid; an assumption that can be tested. 
CHAPTER III

ANALYSIS OF DATA

\section{Quantitative Analysis}

Data of the study was first examined using a percentage basis for the total scores that parents achieved of Agree, Disagree, and Opposite. Comparison of the results of fathers' and mothers' scores are shown in Table $I$.

\section{TABLE I}

DEGREE OF CORRESPONDENCE OF PARENT WITH CHILD BY PER CENT

Agree Disagree $\quad$ Opposite $\quad \mathrm{N}$

$\begin{array}{lllll}\text { Mothers } & 31.5 & 52.1 & 16.31 & 30 \\ \text { Fathers } & 30.52 & 52.6 & 16.84 & 30\end{array}$

In this study parents were able to predict the exact feelings of their children for about thirty per cent of the questions, indicating that in about seventy per cent of the questions they could not predict the exact feelings of their children. Some of the parents' responses would be by chance. At the same time the data show that although parents could not always plck the exact feeling of thein child; in about eightym: three per cent of the questions the parents were able to judge the general feeling tone of their child. That is, parents were able to predict whether their child felt positively or negatively in about eightythree per cent of the questions. Such data would tend to support rejection of the first null hypothesis of this study, that parents' responses 
are the same as that of their children. A test of significance of the figure eighty-three per cent indicates that there is a significant difference from chance at the .01 level. The issue remains, however, both statistically and socially and leaves many questions unanswered. What is the limit of minor to gross misperception by parents of a child's emotional reaction to a situation? What are the cumulative effects of minor misperceptions in minor up to major situations with respect to trust, mistrust, communications and interactions in general? What are the alienation effects of and on communication?

In comparing the results of mothers' responses to the responses of fathers, a chi square was computed and showed no significant difference on scores of Agree, Disagree and Opposite. The second null hypothesis of this study was then accepted, that there was no difference between mothers' and fathers' responses to their children.

Analysis of data by use of a chi square showed that there was no significant difference between mothers' and fathers' responses to their daughters. Further analysis by use of a chi square showed no significant difference of mothers' and fathers' responses to their sons. However, combining both parents' responses and computing a chi square for the difference between parents' responses for daughters and for sons, significant differences were found (See Table II). Taking the schedule as a whole, and giving each item equal weight, there was a significant difference at the five per cent level in the way parents predict feelings of girls and boys, with parents being better able to judge girls than boys. Such data would tend to support rejection of the third null hypothesis of this study, that parents successful predictions of daughters are equal to the successful prediction of sons. 
TABLE II

CHI SQUARE ANALYSIS OF STUDY DATA

\begin{tabular}{llll}
\hline Comparisons & df & $x^{2}$ & $P$ \\
\hline
\end{tabular}

Mothers' scores of children
with
2
0.3122
$>.05$

Fathers' scores of children

Mothers' scores of girls

with

2

0.1896

$>.05$

Fathers' scores of girls

Mothers' scores of boys with scores of boys

2

0.0402

$>.05$

Fathers' scores of boys

Parents' scores of daughters with 2

$\underline{6.5605}$

$<.05>.025$

Parents' scores of sons

In examining the data on parents' scores of daughters and sons it was apparent that there were fewer Opposite scores for daughters, and more Opposite scores for sons (See Table III).

TABLE III

PARENTS' SCORES FOR DAUGHTERS AND SONS

\begin{tabular}{ccccc} 
& N & Agree & Disagree & Opposite \\
$\begin{array}{c}\text { Parents' scores for } \\
\text { daughters }\end{array}$ & 608 & 198 & 325 & 85 \\
\hline $\begin{array}{c}\text { Parents' scores for } \\
\text { sons }\end{array}$ & 532 & 156 & 272 & 104 \\
\hline
\end{tabular}

A test of proportion with respect to the Opposite scores was significant at the .02 level with daughters being better predicted than 
sons.

A Mean was computed on parents' scores of Agree, Disagree and Opposite, primarily for use in a summary report of the study which was offered to parents participating in the study. These results are found in Table IV.

\begin{tabular}{|c|c|c|c|}
\hline \multirow{2}{*}{ MEAN } & SCORES & OF PARENTS & \\
\hline & Agree & Disagree & Opposite \\
\hline & 6 & 9.9 & 3.1 \\
\hline & 5.8 & 10 & 3.2 \\
\hline
\end{tabular}

An extended median test for each category of Agree, Disagree, and Opposite with the variables of education, age, and for mothers and for fathers showed no sfgnificant differences from chance at the :05 level. Parents were separated according to leve1 of education by placement in one of three categories denoting highest level of achievement. These categories were: up to but not including Bachelor's Degree, up to but not including Master's Degree, and Master's' Degree and above. Chi square examinations for both fathers and mothers showed no significant differences as to their scores with reference to level of education. Parent distribution of educational level is shown in Table V.

\section{TABLE V}

EDUCATION LEVEL OF PARENTS

To Bachelor's Degree To Master's Degree Master's Degree and Above 
Examination of parents' age was made in a similar manner with parents being placed above or below an extended median of age, and compared to parents' placement above or below an extended median of scores of Agree, Disagree, and Opposite. Chi square examinations again showed no significant difference from chance. Ages of mothers ranged from twenty-seven to forty-five, with an extended median age of thirty-four. Ages of fathers ranged from twenty-nine to fifty-four with an extended median of thirty-five.

A statistical test. was not used for examination of the ordinal placement of children and parent scores because an inspection of the data revealed no significant differences.

The degree of correspondence of parent with chlld varied greatly on individual questions. Percentage scores of the parents for some of the questions are shown in Table VI. "In question number five of the schedule, only $13.3 \%$ of the parents agreed with their children, while in question number ten, $71.6 \%$ agreed. Quest1on number nineteen had 76.6\% of parents disagreeing, with no responses of an opposite nature, while question number nine had $46.6 \%$ of the parents choosing a feeling opposite in tone to their child's response. Question number five had the largest number of opposite responses by parents with $58.3 \%$ responding in an opposite feeling tone to that of their child. All parents were able to predict the feeling tone for questions number one, six, eight, and nineteen. Questions one and eight had all positive responses by children; and questions six and nineteen had all negative responses. Most of the questions showed a variety of responses from the children, although there was some similarity in some of the questions. Children's responses to some of the questions are shown in Table VII. 
TABLE VI

PERCENTAGE DISTRIBUTION OF PARENT RESPONSES

TO SELECTED SCHEDULE QUESTIONS

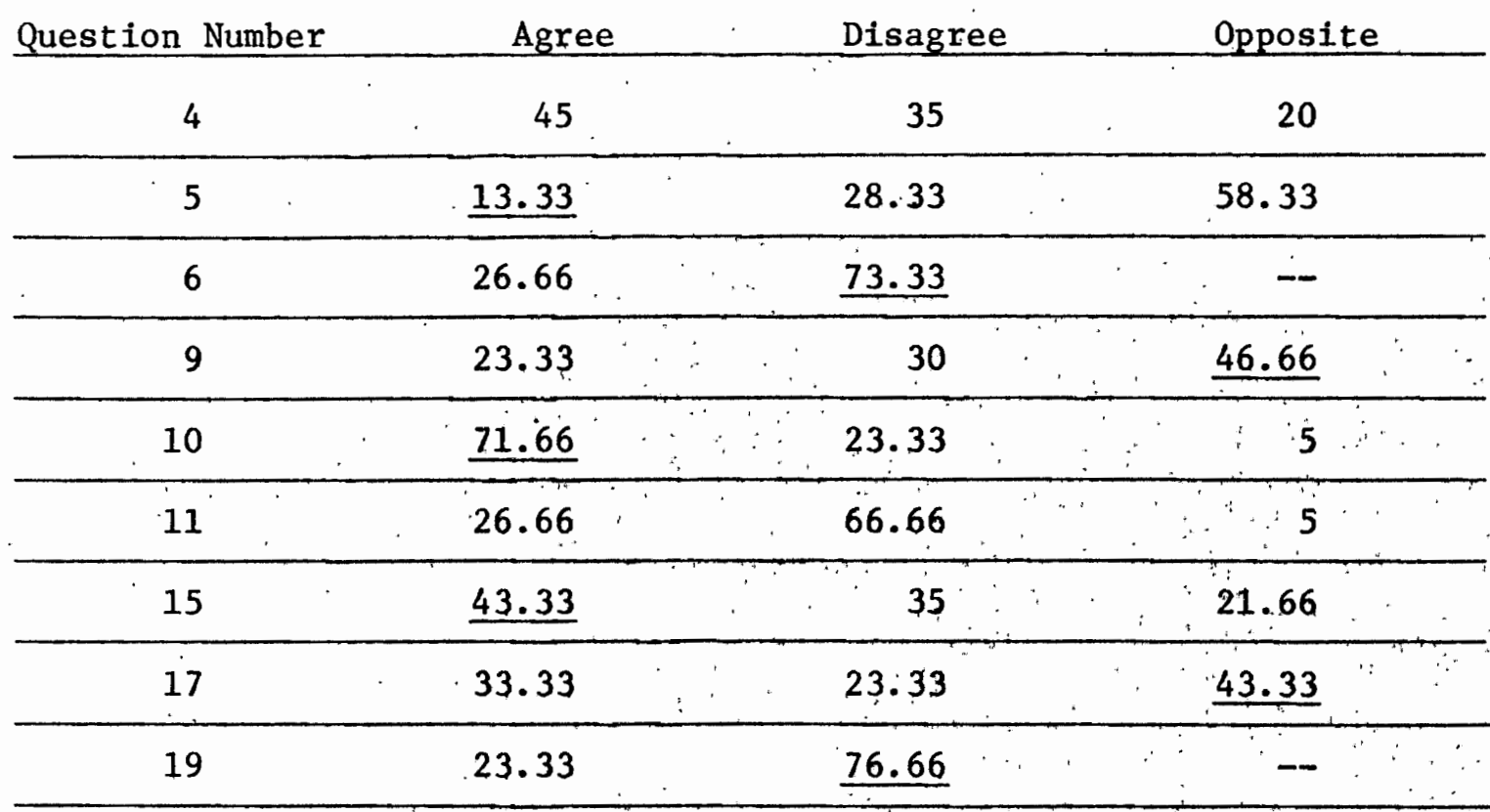

Qualitative Analysis

It was interesting to this writer to note that the two questions of the schedule that dealt specifically with siblings, one of which had a sibling winning a swim race, and the other which dealt with sharing a cookie with a sibiing, were two of the three questions which had the largest percentage of Opposite scores by parents. One mother's comment following her completion of the schedule about these two questions was that she felt parents felt a conflict of desperately wanting their children to feel one thing and not wanting to know that the children feel another. In question number nine when the child was asked what he/she would feel if the brother won a swim race, twenty-one of the thirty children responded with jealous or sad, while nine responded happy, excited, loving, or proud. Almost forty-seven per cent of the parents had an Opposite score for this question. In question number seventeen, 
TABLE VII

EXAMPLES OF CHILDREN'S RESPONSES

TO SELECTED SCHEDULE QUESTIONS

Question Number

Positive Responses

Negative Responses

2

happy -1
excited -3
loving $-\frac{1}{5}$

scared - 10

angry -4

sad

$-\frac{11}{25}$

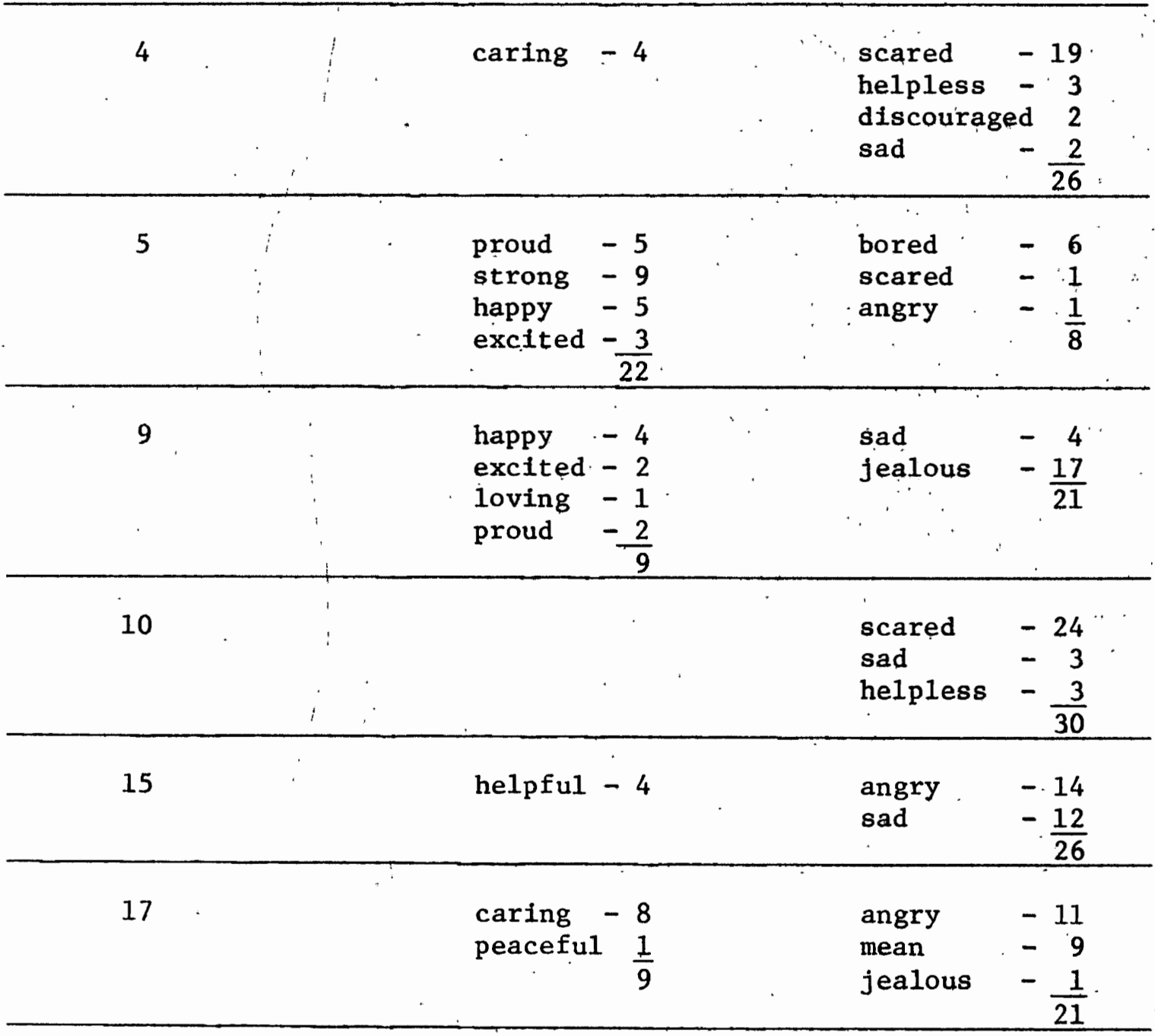

which dealt with sharing a cookie with a brother, twenty-one children responded with jealous, angry, or mean, while nine responded with caring or peaceful. For this question, more than forty-three per cent of the parents had an Opposite score. No effort was made to determine if 
the nine children who responded positively for both of these questions were the same or different for each question.

The other question which caused more than fifty-eight per cent of the parents to respond with an opposite feeling tone, was question number five, which dealt with beginning music lessons and practicing. Here twenty-two of the thirty children responded with a positive reponse of proud, strong, happy, or excited, while eight had a response of bored, scared, or angry.

Children's responses to question number ten, which dealt with having a tonsillectomy, showed twenty-four children responding scared, three stating sad, and three stating helpless. On this question almost seventy-two per cent of the parents agreed with the child.

Several observations of a subjective nature were made during the collection of the data for the study. It was felt by the investigator that although the children were usually a little anxious or nervous about taking part in the study before completing the schedule, they responded well to reassurance and after reading the instructions and answering the sample questions, they. seemed to relax and to a large extent seemed to enjoy taking part in the study. Their responses to the final question on the schedule supported this observation. They were often talkative with the investigator upon completion of the schedule and showed interest in the results of the study. They were often also interested in talking with their parents upon their completion of the schedule, and generally seemed pleased to be the object of the time and attention of both examiner and parents, and that their responses about how they feel should be important enough to be the subject of a study. Some children responded quickly to almost every question, and others 
seemed to take quite awhile in thinking over their response before selecting an answer. Some children seemed barely to glance at the pictures, while others seemed to examine them thoroughly. All seemed interested, however, to see what each picture depicted.

Parents seemed generally more anxious than the children prior to completing the schedule and expressed more difficulty in responding. They frequently commented that it was difficult to separate what they themselves would feel from what they thought their child would feel: A few parents seemed concerned that they would not have a "high score," and all were reassured that the study was exploratory in nature. A11 parents stated that they would be interested in receiving a summary. of the completed study, and many of them wished that they could see their individual results and their child's. Parents were told that they would be given general toţals for their individual responses, but not specific answers to specific questions.

Many parents commented that they felt that by being a part of the study they had increased their awareness. of concern about their child's feelings and felt more inclined to encourage their child to express his/her feelings. All parents who were in personal contact with the investigator commented that many times they believed they knew what their children were feeling, and because of this they did not ask their children to express these feelings. After taking part in the study, many parents stated that they were curious as to whether their assumptions about their children's feelings have been correct.

From the results of this study it seems evident that children's feeling reactions to the same objective situation vary considerably. For parents attempting to predict these reactions there are additional 
problems. Besides the variation in individual responses by children, parents must also consider that their own feeling response may influence how they think their child would respond. Parents' desires or hopes may also affect the way they judge their children's feelings. Such problems compound and make the task of predicting children's feelings a difficult one, yet one that many parents believe they often attempt to do. It would seem important then for social workers to be constantly aware of the great diversity of feelings to the same situation and the need for clarification of feelings. 
CHAPTER IV

CONCLUSIONS

Because this study was exploratory in nature, it was somewhat difficult to draw many specific conclustons. Even before the data was analyzed, it was the opinion of this writer after conducting the study and listening to the comments of the parents involved, that the subject of parents' predicting or assuming that they know the feelings of their children, is one that warrants more research and concern. Social Work continues to be interested in family life, parent-child interaction, elements of good communication, and the awareness and expression of feelings. This study touches on all of these areas of concern.

Results of the data show that much of the time parents are able to predict whether their children would feel positively or negatively toward a specific situation, but are not well able to predict specific feelings. This may contribute to the idea that a parent thinks he knows what his/her child is feeling or will feel, while the child may be feeling that his/her parents don't really understand them. Social Work is interested in such gaps in understanding as well as the problems they lead to in communication between parent and child.' Social workers are in the position of being able to apply the knowledge of the need for accurate perceptions of specific feelings. Parents could be helped to see the need of ascertaining specific feeling responses of their children. By parents probing for more exact expression of feelings, 
children might be helped to become more aware of their own feelings, as well as increase their ability to express their feelings. Such a basic element in good communication, if learned and practiced while children are young, could perhaps be carried over into other communication with peers and eventually into adult life.. Such could hold true for others working with children, such as teachers.

In stating that parents in this study were able to predict the feeling tone of their child for eighty-three per cent of the situations, this writer felt that she was being particularly generous to the parents. It seemed appropriate to credit the parents for recognition of the feeling tone. when the responses were of a positive nature. It is doubtful that it would be of much importance to distingulsh between whether a child is feeling happy or excited, or helpful or caring. However, there seems to be much difference in the psychological dynamics between many of the negative responses, and it is this writer's opinion that it is of much importance to distinguish between them. There is considerable difference between feeling angry and sad, or in feeling helpless or mean, guilty or bored. One suggestion for future study would be to examine parents' perceptions of specific negative feelings. of particular interest to this writer was the study data which showed that parents are less able to predict the feelings of their sons than of their daughters. One might hypothesize that ten-year-old boys in our culture have already become adept at hiding their feelings, even from their parents, or that parents pay less attention to the feelings 'of their sons, or tend to stereotype boys' feelings more than girls'. This diffèrence between sons and daughters was markedly illustrated in two subjects of the study who were ten-year-old brother and sister 
twins. The combined Opposite scores of both parents for the twin girl was three, while the combined Opposite scores for the twin boy was eleven. For Social Work this could indicate a need for increased awareness and effort in examining the repression of feelings for males of a11 ages.

One comment occasionally expressed by parents was that although they felt they often did assume that they knew what their child was feeling, in real life situations they based such assumptions on observations of the child's behavior and non-verbal clues. It is this writer's opinion that such things may help in ascertaining a feeling, but may also add to confusion and misunderstanding of feelings as well. Tears can often indicate other feelings than sadness. Aggressive, acting out behavior can often mask other feelings than anger. While examination of feelings by use of a schedule is a contrived situation, a real-life situation may also make more difficult the parents' predictions of their children.

A critique of this study would reveal several observations. No effort was made to evaluate the honesty and consistency of the children's responses and this effect on the study's validity. One suggestion would then be to repeat the schedule with the children at a later time. Another problem that may have affected the study results would concern a possible temporal bias. Interviews with children and parents were conducted over a six week period, allowing for some discussion of the schedule amongst the children, although they were instructed not to do so. Another suggestion for future study would be the selection of a random sample, rather than a cluster sample of children. 
$\underline{\text { Summary }}$

For the sample studied, the results of this study could be summarized by the following:

1. Parents were able to predict the general feeling tone of their children in about eighty-three per cent of the study situations.

2. Parents were able to predict the exact feelings of their children in about thirty per cent of the study situations.

3. Fathers and mothers were equally good predictors of their children.

4. Fathers and mothers of daughters were better able to predict their children's feelings than were fathers and mothers of sons.

5. Children's feeling responses to the same objective situations varied considerably, often in opposite directions.

6. Parents' ability to predict was greater for some situations than for others.

Such findings indicate the need for further study of the types of situations in which parents are more or less able to predict. It is also apparent that children's feelings can not be stereotyped and that further studies are needed in examining the consistency and variability of children. There were also many historical and intervening variables that were not examined in this study that indicate the need for further research, such as maturity, family style, intelligence, verbal ability and critical incidents, both singly and together. 


\section{REFERENCES CITED}

Be11, John Elderkin. Projective Techniques: A Dynamic Approach to the Study of the Personality. New York: Longmans, Green and Co., 1948 .

Bledson, Joseph C. "Congruence of Adolescents' Self-Concepts and Parents' Perceptions of Adolescents' Self-Concepts", Journal of Psychology, 83 (1973), 131-136.

Frank, Lawrence K. Projective Methods. Springfield: Charles C. Thomas, Publisher, 1948.

Kessler, Jane W. The Psychopathology of Childhood. Englewood Cliffs, New Jersey: Prentice Hall Inc., 1966.

Langford, Louise M. and 0. W. Alm. "A Comparison of Parent Judgements and Child Feelings Concerning the Self Adjustment and Social Adjustment of Twelve-Year-0ld Children." The Journal of Genetic Psychology, 85 (1954), 39-46.

Leichter, H. J., and Mitche11; W. E. Kinship and Casework. New York: Russe11 Sage Foundation, 1967.

Meyer, Carol H. Social Work Practice: Second Edition.- New York: The Free Press, 1976.

Piers, Ellen V. "Parent Prediction of Children's Self-Concepts." Journal of Consulting and Clinical Psychology, 38 (1972), 428-433.

Satir, Virginia. Peoplemaking. Palo Alto: Science and Behavior Books, Inc., 1972 . 
APPENDIX A 
Present age ...... Date of tirthday

Sex

Number of older brothers in the home

Number of older sisters in the home

Number of younger brothers in the home

Number of younger sisters in the home 
Thank you for taking part in this study. It is about children's feelings. It is NOT a test and there are NO right or wrong answers to these questions. Please DD NOT put your name on this paper. Your parents will also be answering these questions. Neither you nor your parents will be allowed to see the completed questions. Take your time and try to answer all questions honestly. After reading each question, stop for a moment and think about your feelings. Then look on the "LIST OF FEELINGS" on the opposite page, and choose one word that best describes how you feel. Write thet word in the blank space. Do NOT answer how you think you should feel, but answer how you do feel. If no word on the list describes youx feelings, choose the ward that comes closest to what you feel. If you have any questions at any time, be sure to ask. Carefully read through the "LIST DF. FEELINGS" now.

\section{EXAMPLE}

1. Look at picture \#1. It is Jane's birthday today." Jane has been wanting a special set of dolls, and hoped that her parents would get them for her. When she opened the gift from her parents she saw the dolls that she wanted. Pretendr that you are Jane. What are you feeling? 1.

2. Look at picture \#2. John and his brother and sister went fishing with their father. John had never caught a fish before. Today John caught a fish and his father caught two fish. Pretend that you are John. What are you feeling? 2. 
1. Look at picture \#1. Joan and her family have gone to the beach for the day. They decide to build a sand cestle on the beach. They all work very hard and build a big castle. Pretend that you are Joan. What are you feeling?

2. Look at picture \#2. Pretend that your father kis taken a new job and you and your family must move to a different city. On moving day you come home from school and find all the furniture moved out of your house. What are you feeling?

2.

3. Look at picture \#3. Bob's mother just bought a new shirt and pair of pants for Bob. He puts the new clothes on and goes outside. When playing baseball he gets two home runs, but gets his new clothes dirty. Bob sees his mother when he gets home. Pretend that you are 'Bob.:" What are you feeling?

3..

4. Look at picture \#4. Judy's parents wake up one night smelling smoke. Their house was on fire. 'Judy's parents got her out of bed and the family quickly runs outside. Pretend that you are Judy. What are you feeling?

4.

5. Look at picture \#5. Eric is going to learn to play the drum. He has taken one lesson, and will practice every day. Eric's mother reminds him that it is time to practice his drum losson. Pretand that you are Eric. What are you feeling?

5.

6. Look at picture \#6. Pretend that your mother asked you to do last night's dishes when you get home from school. You plan to do the dishes but get interested in a TV program and forget. Mother comes home and sees the dishes. What are you feeling? : 6. 
7. Look at picture \#7. Sam and his friends are playing ball. Sam hits the ball which breaks the window of Mr. Jones' officc. Sam and two friends go over to Mr. Jones to get their ball back. Pretend that you are Sam. What are you feeling?

7 .

8. Look at picture \#8. Pretand that your class at school has gone on a field trip to a big park. On a hike through tho park you are walking with your best friend. What are you feeling?

8.

9. Look at picture \#9. Pretend that you have a brother who ijs on the park swim team. Your brother is a fast swimmer and has just waph his race. After the race you see your mother go over to your brother. What are you feeling? 9.

10. Look at picture \#10., Krịs has had many sore throats and the doctor says that she must have her tonsils out. Today is the day her mother will take her to the hospital to have her tonsils out. Kris's mother says that. it is time to go...Pretend that you are Kris. 'What are you feeling?

10.

11. Look at picture \#11. Pretend that you and your friends are playing in the park. One of the boys brings out a pack of cigarettes and starts to smoke one. What are you feeling? 11.

12. Look at picture 412 . Jim's father loves to play softball. He gave Jim. a glove and ball for his birthday last year and frequently wants to play catch with Jim. Jim does not like to play softball or catch. His father has just asked him to come out and play catch. Pretend that you are Jim. What are you feeling?

12. 
13. Look at picture $f_{13}$. The teacher has asked the class to read Chapter 6 in the book. She says that anyone who has not read it should stay in from recess to do so. Gary has not read. the chapter but goes out to play at recess time. After reçess, the teacher says that she will give a test on Chapter 6. Pretend that you are Gary. What are. you feeling?

13.

14. Look at picture \#14. Pretend that your class is putting on the play "Three Blind Mice" för Parents Night: You were not óne of those chosen to have a part in the Rlay: What are you fealing?

1.4.

15. Look at picture \#15.. Jane's friend has called and asked Jâne to go to the beach today. Jane's parents saịd that since Jane was gona Iast weekend and unable to help at home; she must stay home today and help the family work in the yard. Pretend that you are Jane. What are you feeling?

15.

16. Look at picture \#16. Joe and three of his friends aro walking home from school. The boys have a disagreement and Joe's three friends walk off without him. Pretend that you are Joe. What are you feeling?

16.

17. Look at picture \#17. Susie is hungry after school. There is only one chocolate chip cookie left. Susie's mother says that she must share the cookie with her little brother. Pretend that you are Susie. What are you feeling? 17 .

18. Look at picture \#18. Sharon and her family live on a farm. She. and her brothers help their father put the hay in the barr at harvest time. Pretend that you are Sharon. What are you feeling? 
19. Look at picture \#19. John plays on a Little League Softball team. John's team has two outs and it is his turn to be up at bat. John misses the ball three times and strikes out. Pretend that you are John. What are you feeling? 19.

20. There is no picture for this story. Bill is a boy who was asked to take part in a special study about children's foelings. Bill looked at many pictures and answered many questions. Bill is now through with the study. Pretend that you are Bill. What are you feeling? You may use any word you like, it does not need to be on the List of feelings. 20. 
APPENDIX B 
Children's. Feelings Survey

Parents' Responses

No. 


\section{INSTRUCTIONS}

Thank you for taking part in this study. It is a study of children's feelings and the parents' predictions of these feelings. As such, there are NO right or wrong answers to. the questions. You are asked to respond to the questions as you think your child would respond. Please do NOT put your name on these papers. All questionnaires will remain anonymous and will be linked with your child's rosporisens only by. a coded number. A summary of the overall results of the stidy will be sent to you upon its completion if you so desire. Take your tijme and try to answer each question as you think your child would answer. After reading each question, think for a moment about how you, thinik your child would feel. Then choose orie word from the "LIST OF FEELINGS": on the opposite page that best describas that fealing. Write the word in the blank space. If no word on the list describes what you think they feel, choose the word that comes closest to that feeling. Please read through the LIST OF FEELINGS now.

\section{EXAMPLE}

1. Look at picture \#1. It is Jane's birthday todey. Jane has been wanting a special set of dolls, and hoped that hex parents would get them for her. When she opened the gift from her parents she saw the dolls that she wanted. Pretend that you are Jane. What are you feeling?

2. Look at picture \#2. John and his brother and sister went fishing with their father. John had never caught a fish before. Today John caught a fish and his father caught two fish. Pretend that you are John. What are you feeling? 
RESPOND 65 YOU THINK YOUR CHILD. WOULD RESPOND

1. Look at picture \#1. Joan and her femily have gone to the beach for the day. They decide to build a sand castle on the beach. They all work very hard and build a big castle: Pretend that you are Joan. What are you feeling?

2. Look at picture H2. Pretend that your father his taken a new job and you and your family must move to a different city. On moving day you come home from school and find all the furniture moved out of your house. What are you feeling?

2 .

3. Look at picture \#3. Bob's mother just bought a new shirt and, pair of pants for Bob. He puts the new clothes on and goeṣ ouțside. When playing baseball he gets two home runs, but gets his new clothes dirty. Bob sees his mother when he gets home, Pretend that you are Bob:" What are you feeling?

3.

4. Look at picture \#4: Judy's parents woke up one night smelling smoke. Their house.was on fire. Judy's parents got her out of bed and the family quickly runs outside. Pretend that you are Judy. What are you feeling?

4.:

5. Look at picture \#5. Eric is going to learn to play the drum. He has taken one lesson, and will practice every day: Exic's mother reminds him that it is time to practice his drum lesson. Pretend that you are Eric: What are you feeling?

5.

6. Look at picture \#6. Pretend that your mother asked you to do last 'night's dishes when you get home from school. You plan to do the dishes but get interested in a TV program and forget. Mother comes home and sees the dishes. What are you feeling?

6. 


\section{RESPOND AS YUU THINK YOUR CHILD WOULD RESPOND}

7. Look at picture \#7. Sam and his friends are playing ball. Sam hits the ball which breaks the window of Mr. Jones' officc. Sam and two friends go over to MI. Jones to get their ball back. Pretend that you are Sam. What are you feeling?

8. Look at pioture \#日. Pretand that your class at school has gone on a field trip to a big park. On a hike through the park you are walking with your best friend. What are you feeling?

8.

9. Look at picture \#9. Pretend that you have a brothex who is on the park swim team. Your brather is a fast swimmer and has just won his race. After the race you see your mother go over to your brother. What are you feeling?

10. Look at picture \#10. Kris has had many sore throats and the doctor says that she must have her tonsils out. Today is the day her mother will take her to the hospital to have her tonsils out. Kris's mother says that it is time to go. Pretend that you are Kris. What are you feeling?

10.

11. Look at picture \#11. Pretend that you and your friends are playing in the park. One of the boys brings out a pack of cigarettes and starts to smoke one. What are you feeling?

11.

12. Look at picture 412 . Jim's father loves to play softball. He gave Jim a glove and ball for his birthday last yaar and frequently wants to play catch with Jim. Jim does not like to play softball or catch. His father has just asked him to come out and play catch.' Pretend that you are Jim. What are you feeling?

12. 
RESPOND IS YOU THINK YCUR CHILD WOULD RESPOND

13. Look at picture 13 . The teacher has asked the class to read Chapter 6 in the book. She says that anyone who has not read it should stay in from recess to do so. Gary has not read the chapter but goes out to play at recess time. After recess,. the tencher says that she will give a test on Chapter 6. Pretend that you are Gary. What are you feeling?

13.

14. Look at picture \#14. Pretend that your class is putting on the play "Three Blind Mice" for Parents Night. You were not one of those chosen to have a part in the pliay: What are you feeiting?

14.

15. Look at picture \#15. Jane's friend has called and asked Jane to go to the beach today. Janel's parents said that since Jane was gothe last weekend and unable to help at home, she must stay home today and help the family work in the yard. Pretend that you are Jane. What are you feeling?

15.

16. Look at picture $\# 16$. loe and three of his friends are walking home from school. The boys have a disagreement and Joe's three friends walk off without him. Pretend that you are. Joe. What are you feeling?

$$
16 .
$$

17. Look at picture \#17. Susie is hungry after school. There is only one chocolate chip cookie left. Susie's mother says that she must share the cookie with her little brother. Pretend that you are Susie. What are you feeling?

17.

18. Look at picture \#18. Sharon and her family live on a farm. She and her brothers help their father put the hay in the barn at harvest time. Pretend that you are Sharon. What are you feeling?

18. 
RESPOND AS YOU THINK YOUR CHILD WOULD RESPOND

19. Look at picture \#19. John plays on n Little League Softball team. John's team his two outs and it is his turn tö be up at bat. John misses the ball three times and strikes out. Pretend that you are john. What are you feeling? 19.

20. There is no picture for this story. Bill is a boy whio was asked to take part in a special study about children's foelings. Bill looked at many pictures and answered many questions. . Bill is now through with the study. Pretend that you are Bill. What are you feeling? You may use any word you like, it does not need to bo on the list of Feelings. 20. 
APPENDIX C 


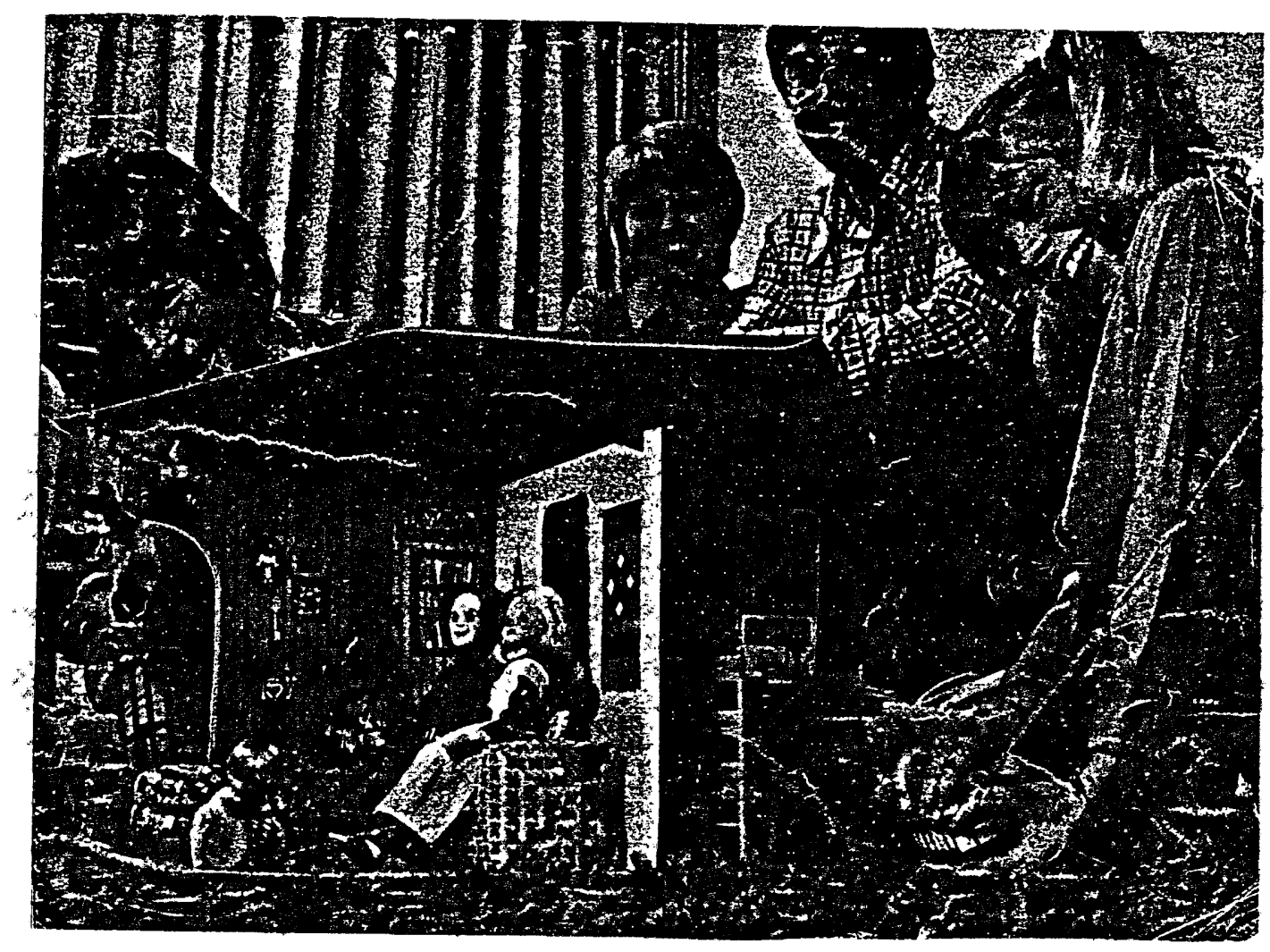

Sample Picture No. 1 


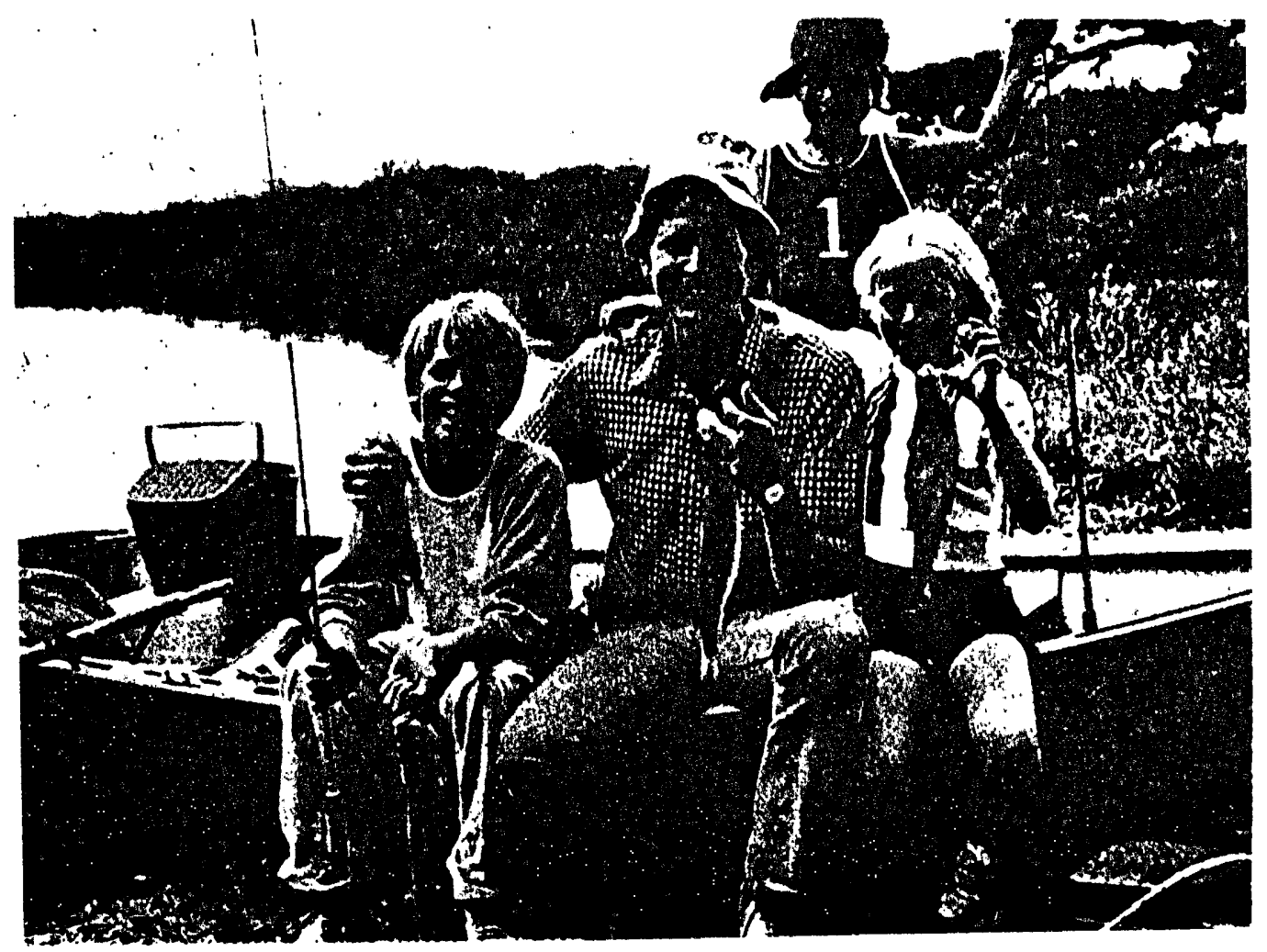

Sample Picture No. 2 


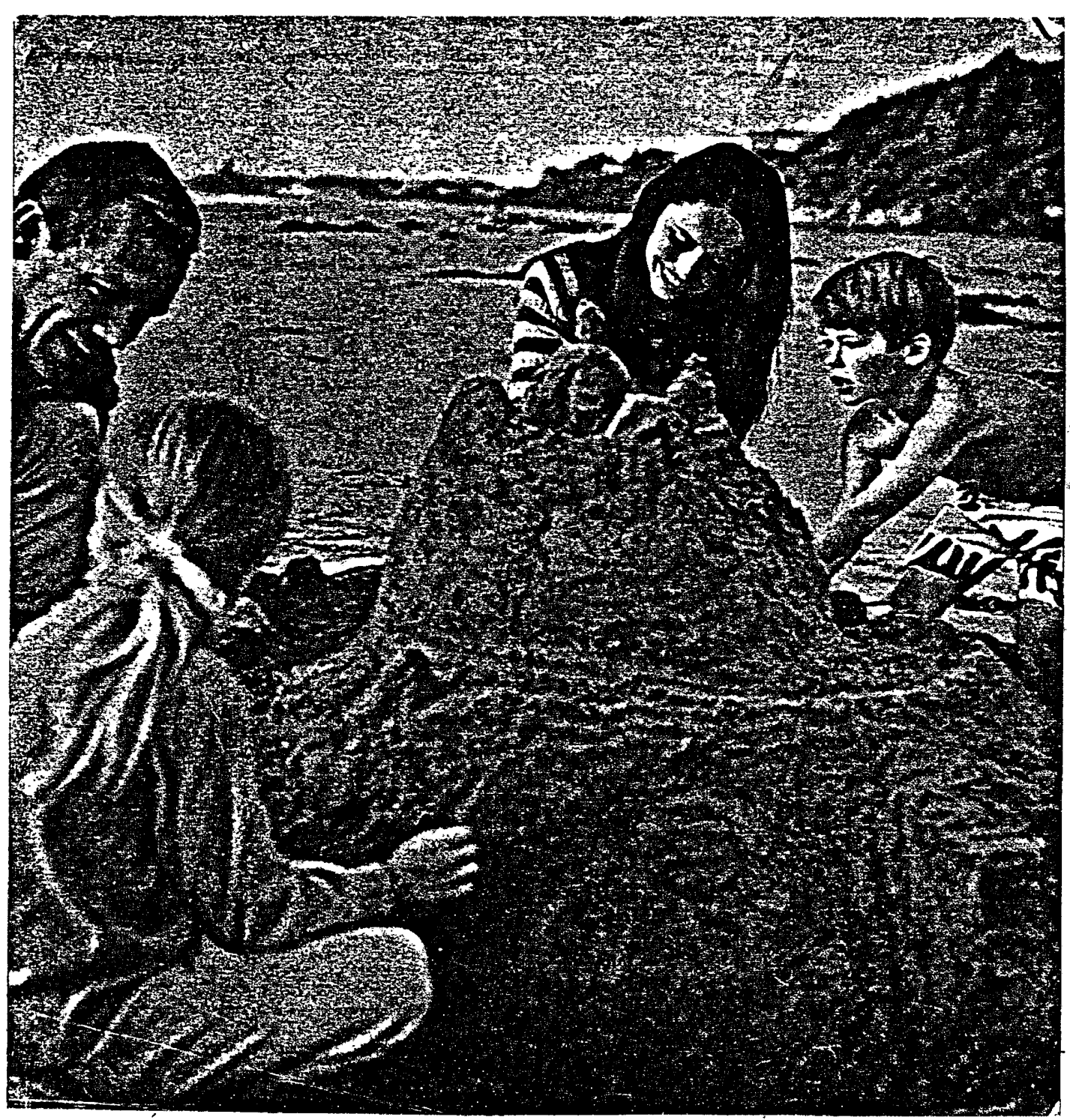

Picture No. $\overline{1}$ 


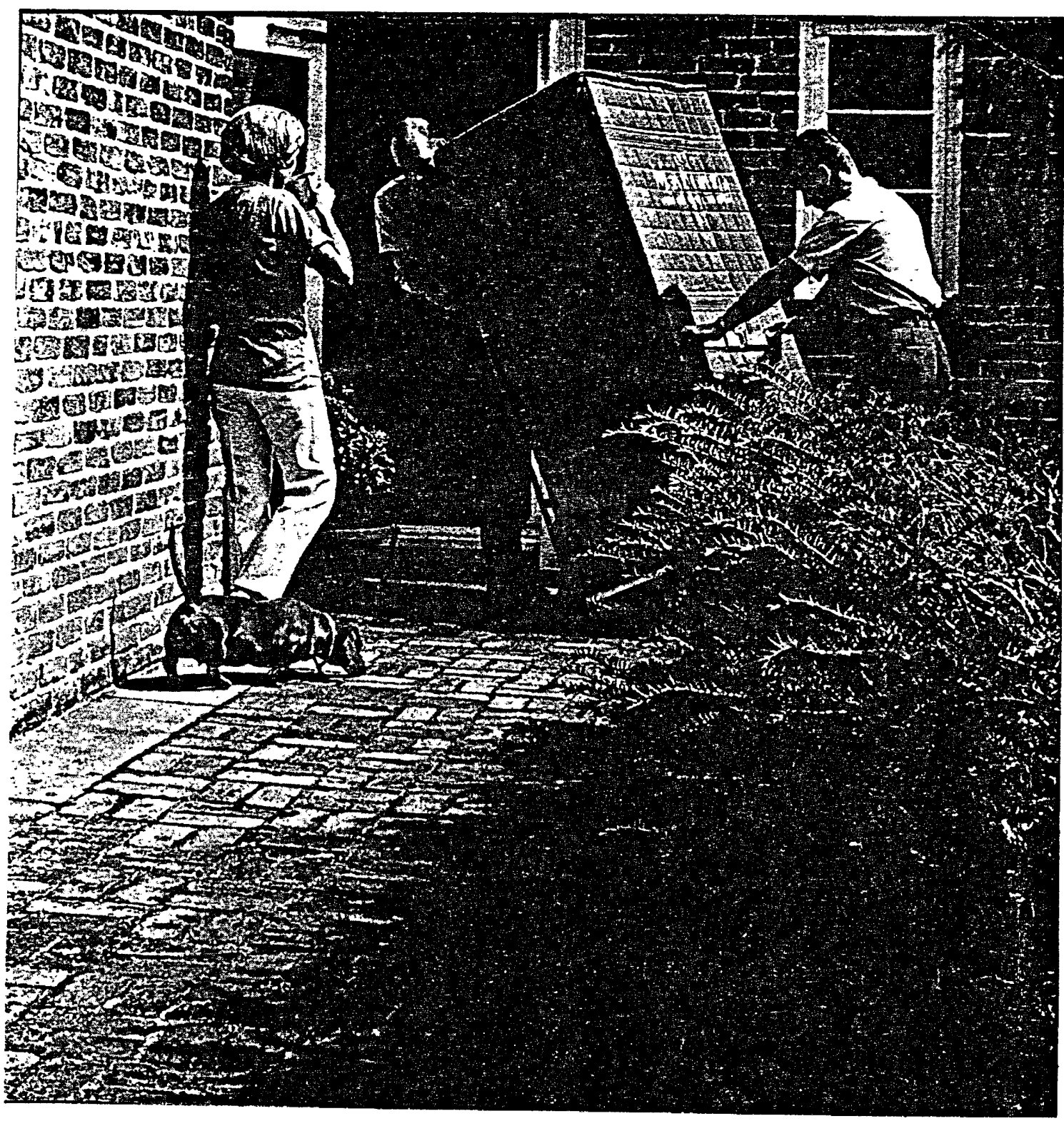

Picture No. 2 


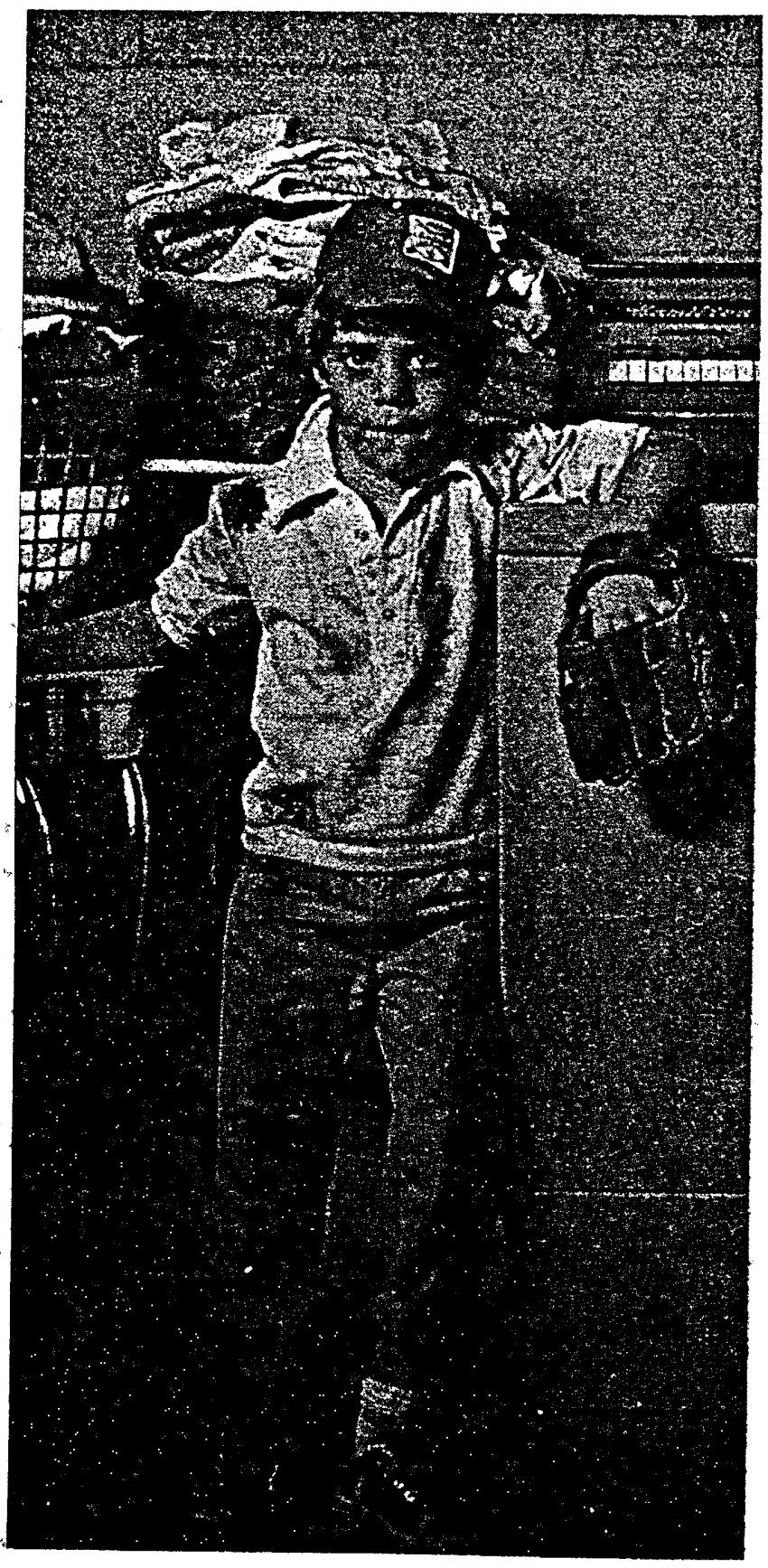

Picture No. 3 


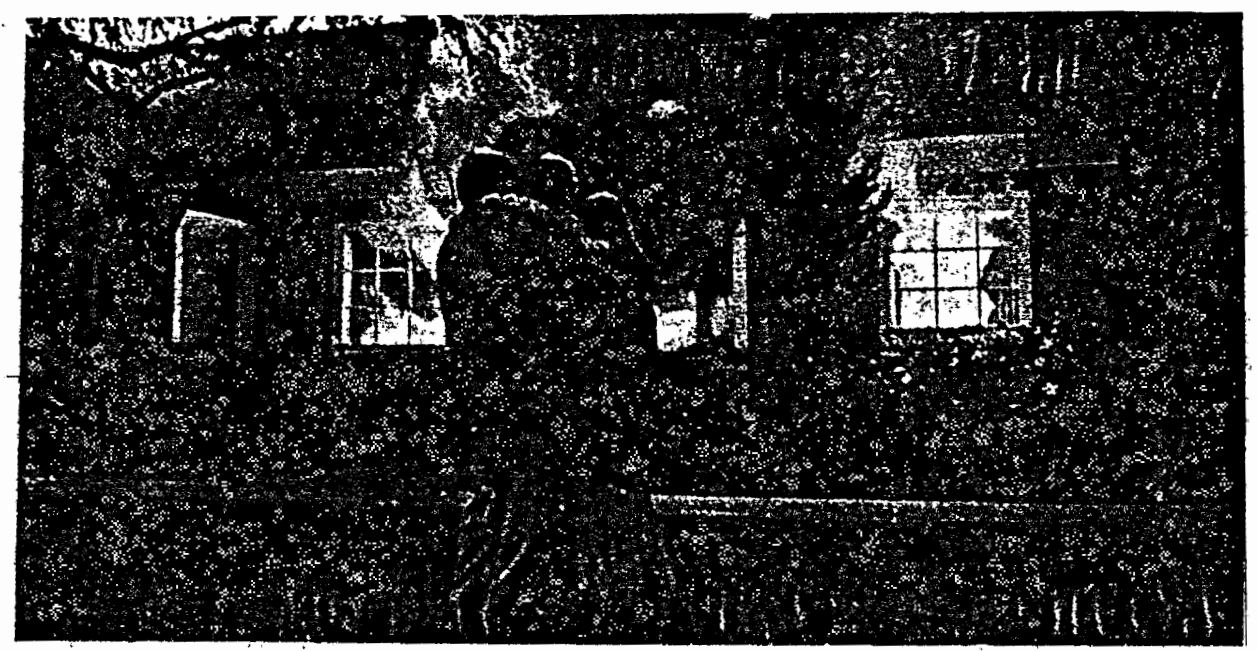

Picture No. 4 


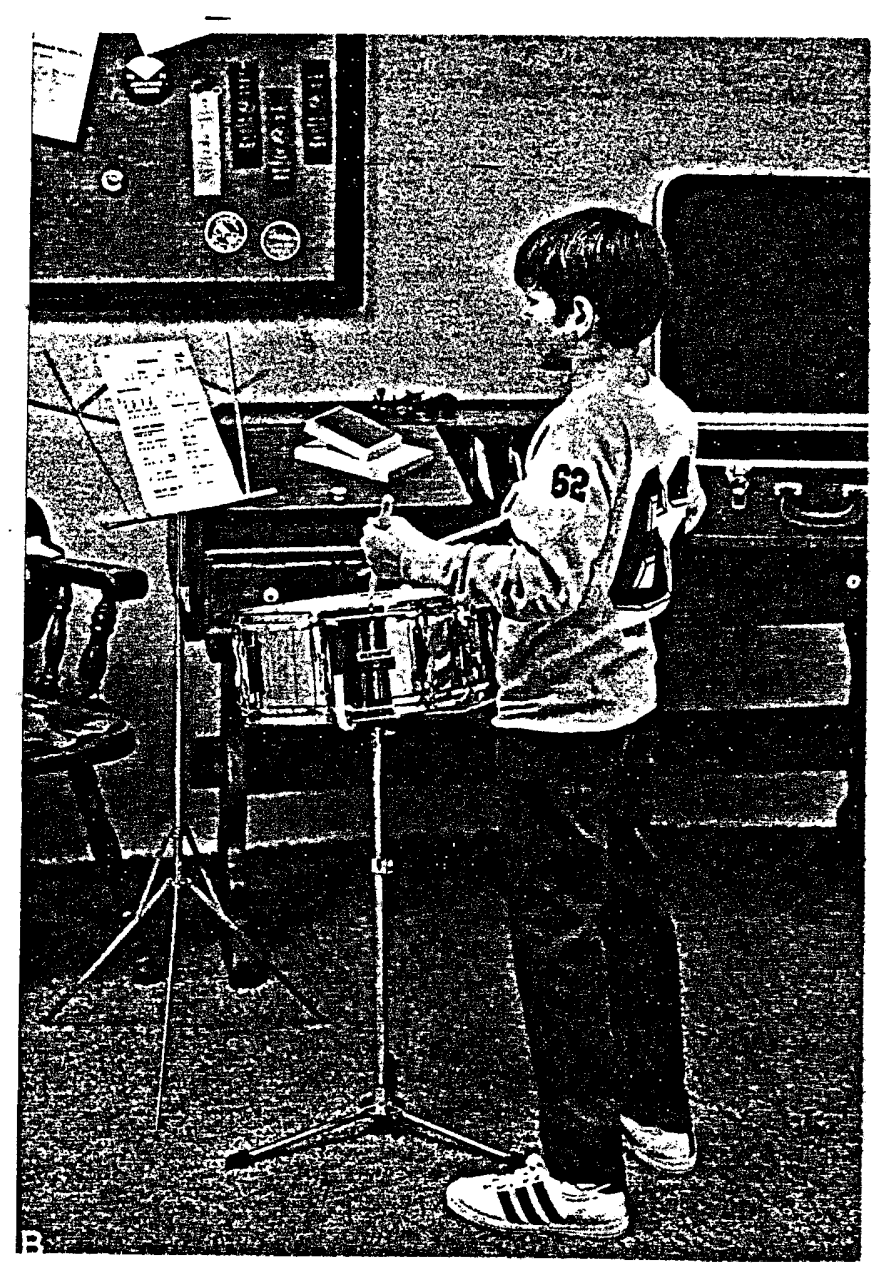

Picture No. 5 


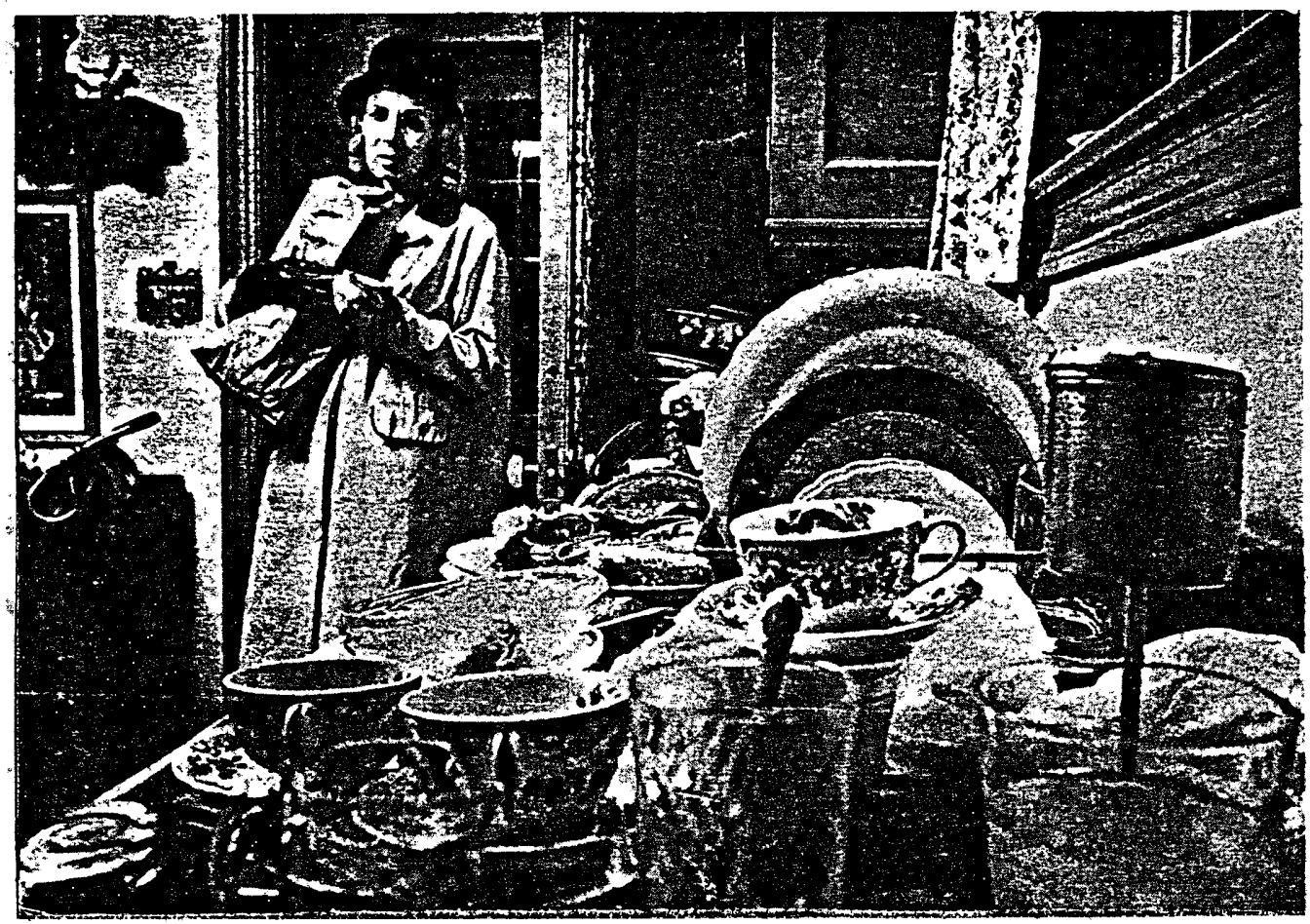

Picture No. 6 


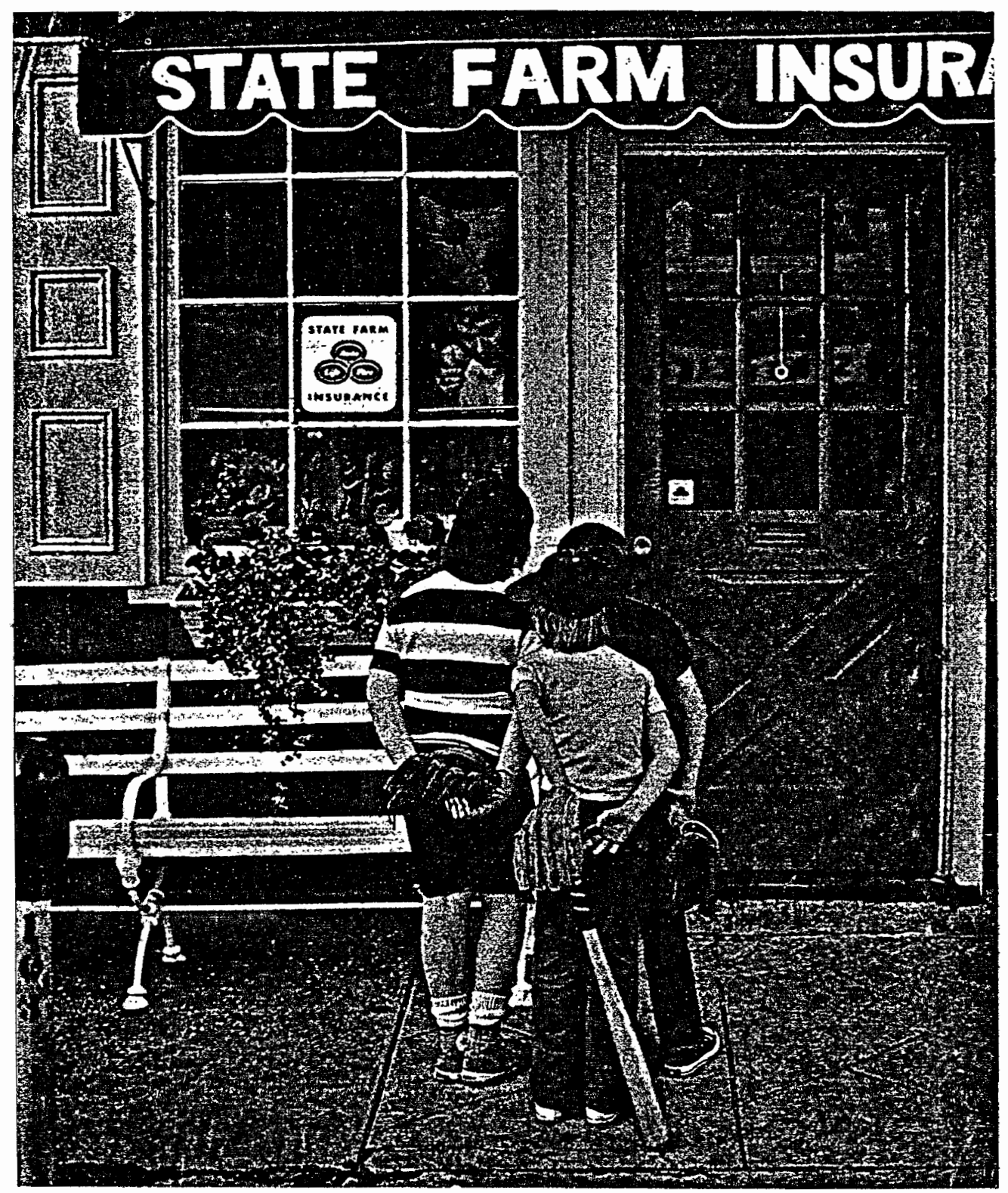

Picture No. $?$ 


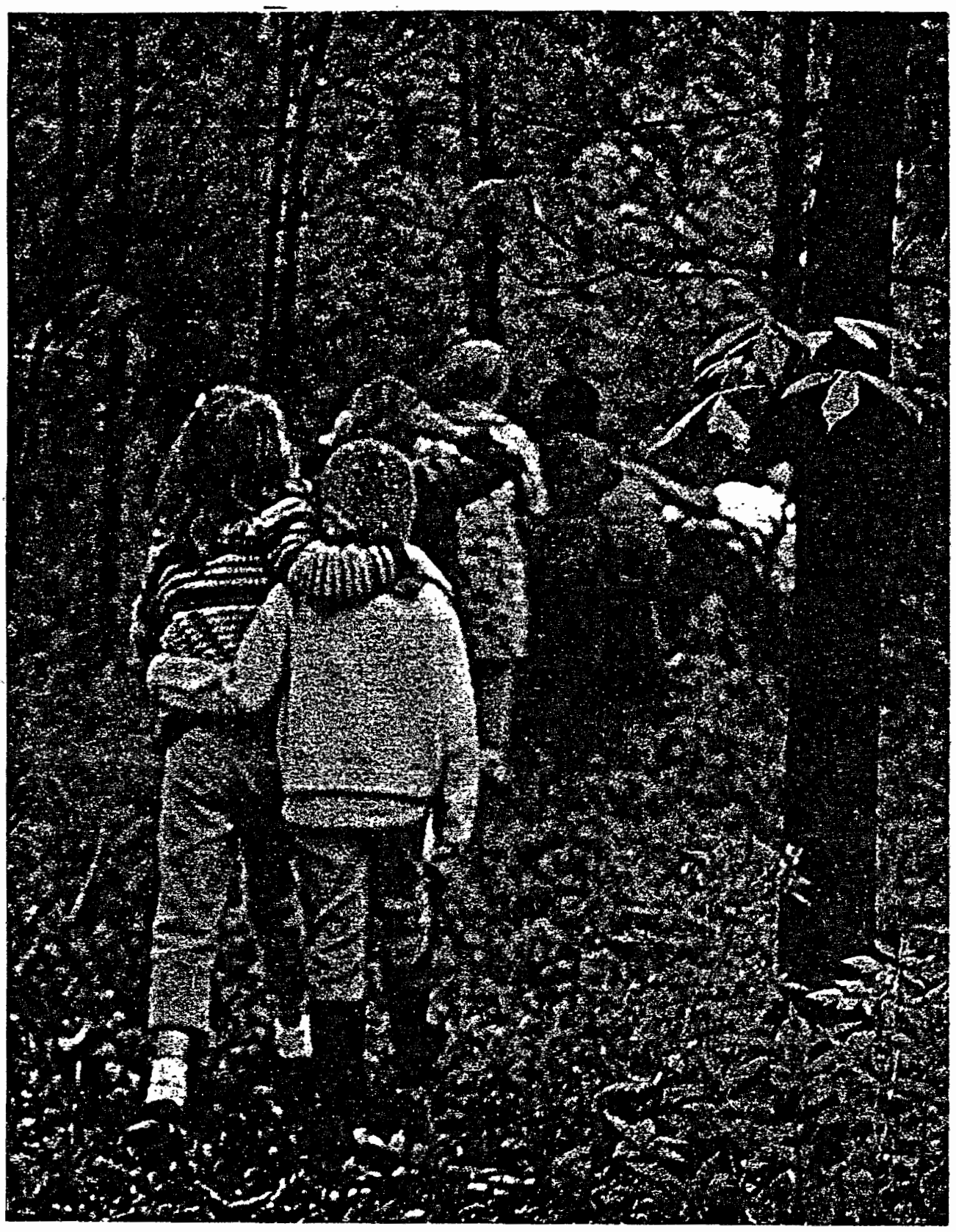

Picture No. 8 


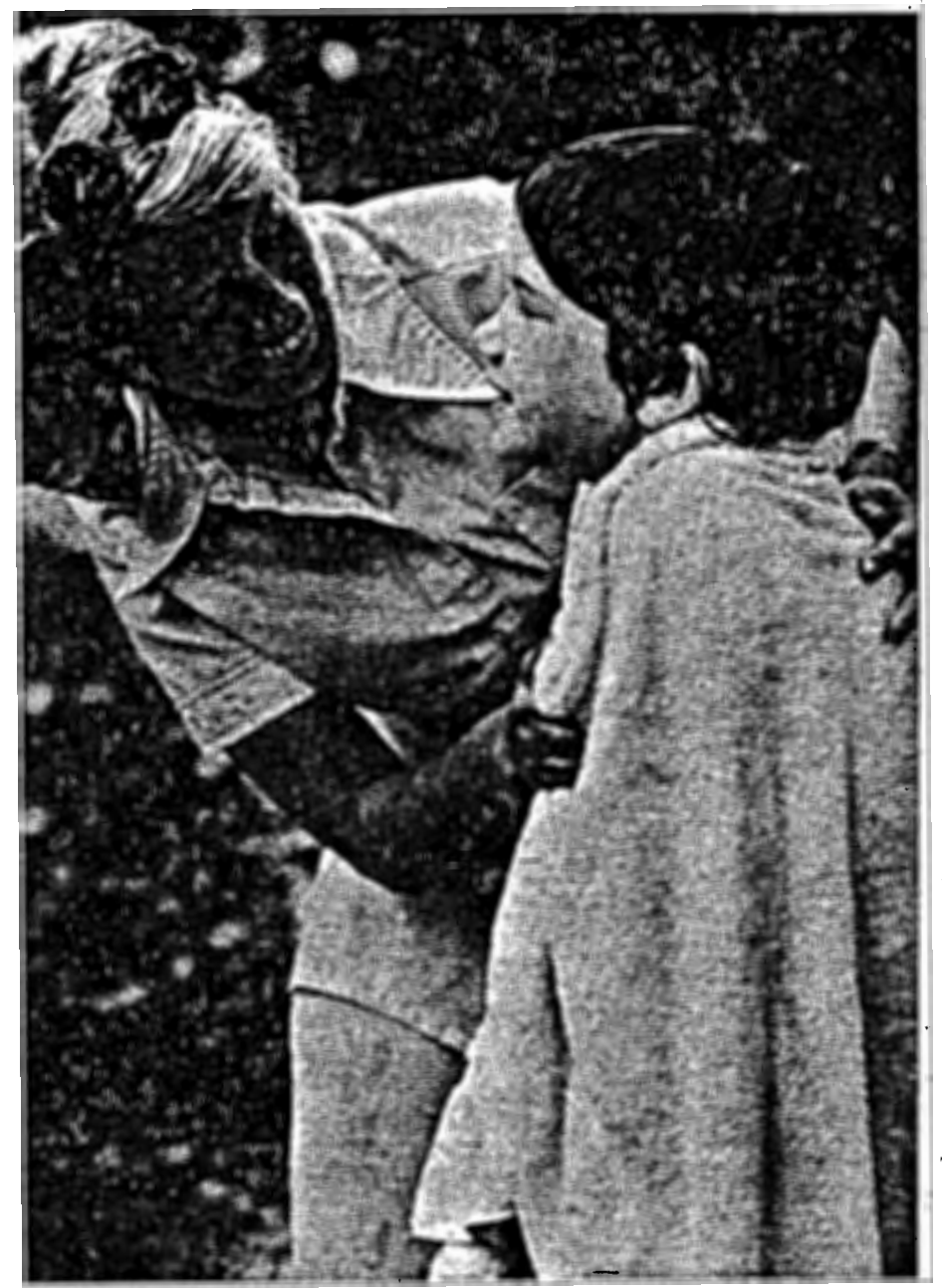

Picture No. 9 


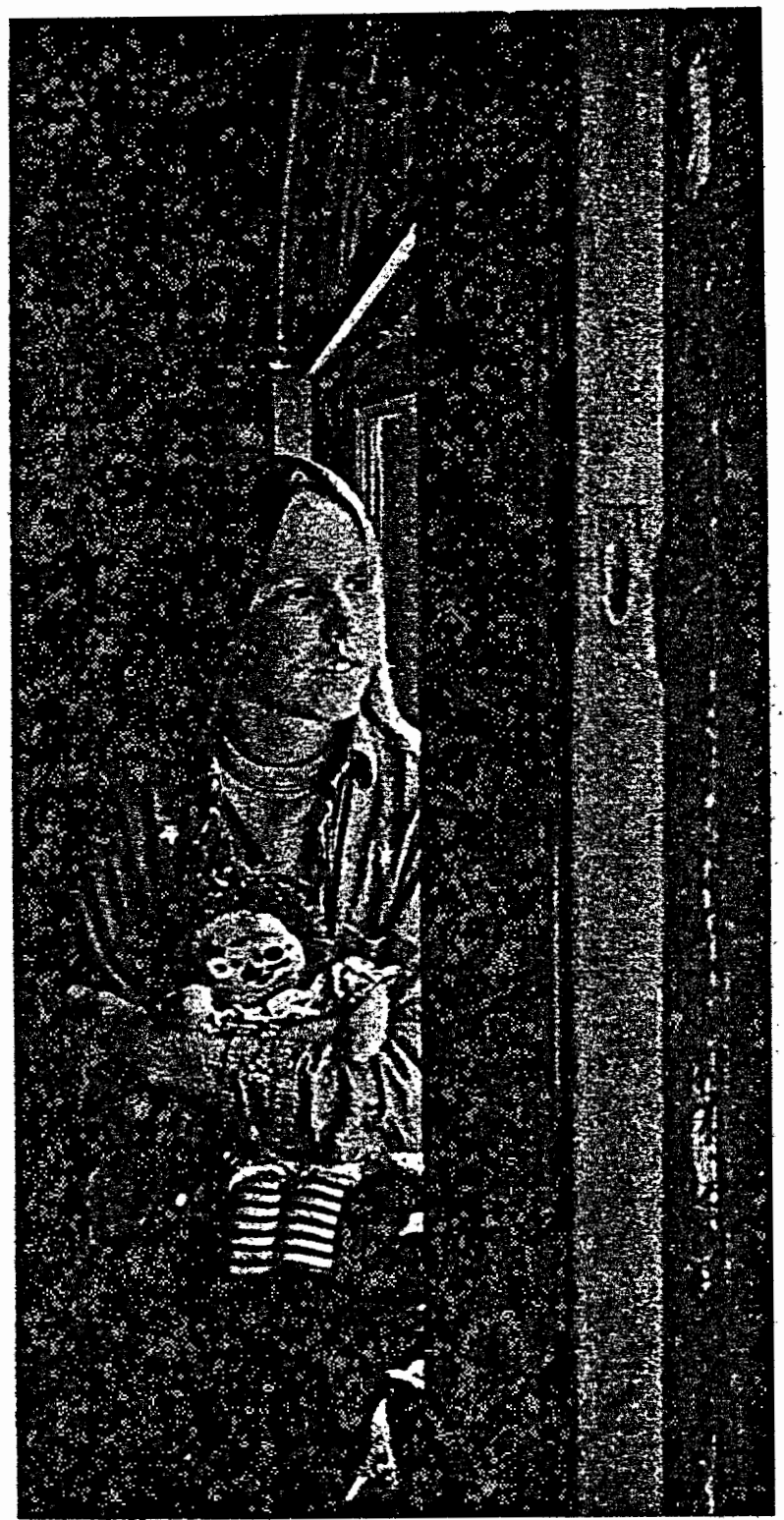

Picture No. 10 


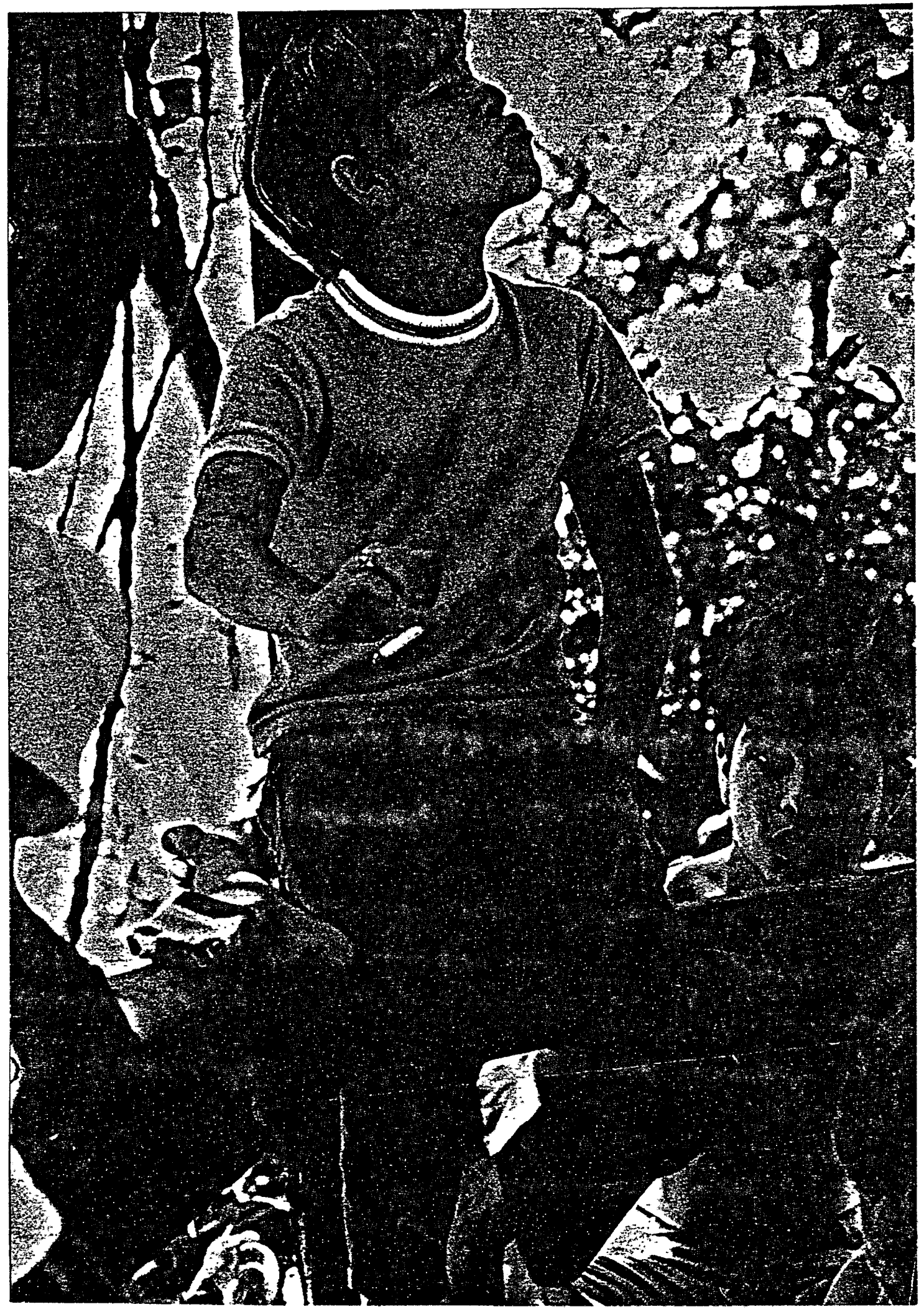

Picture No. 11 


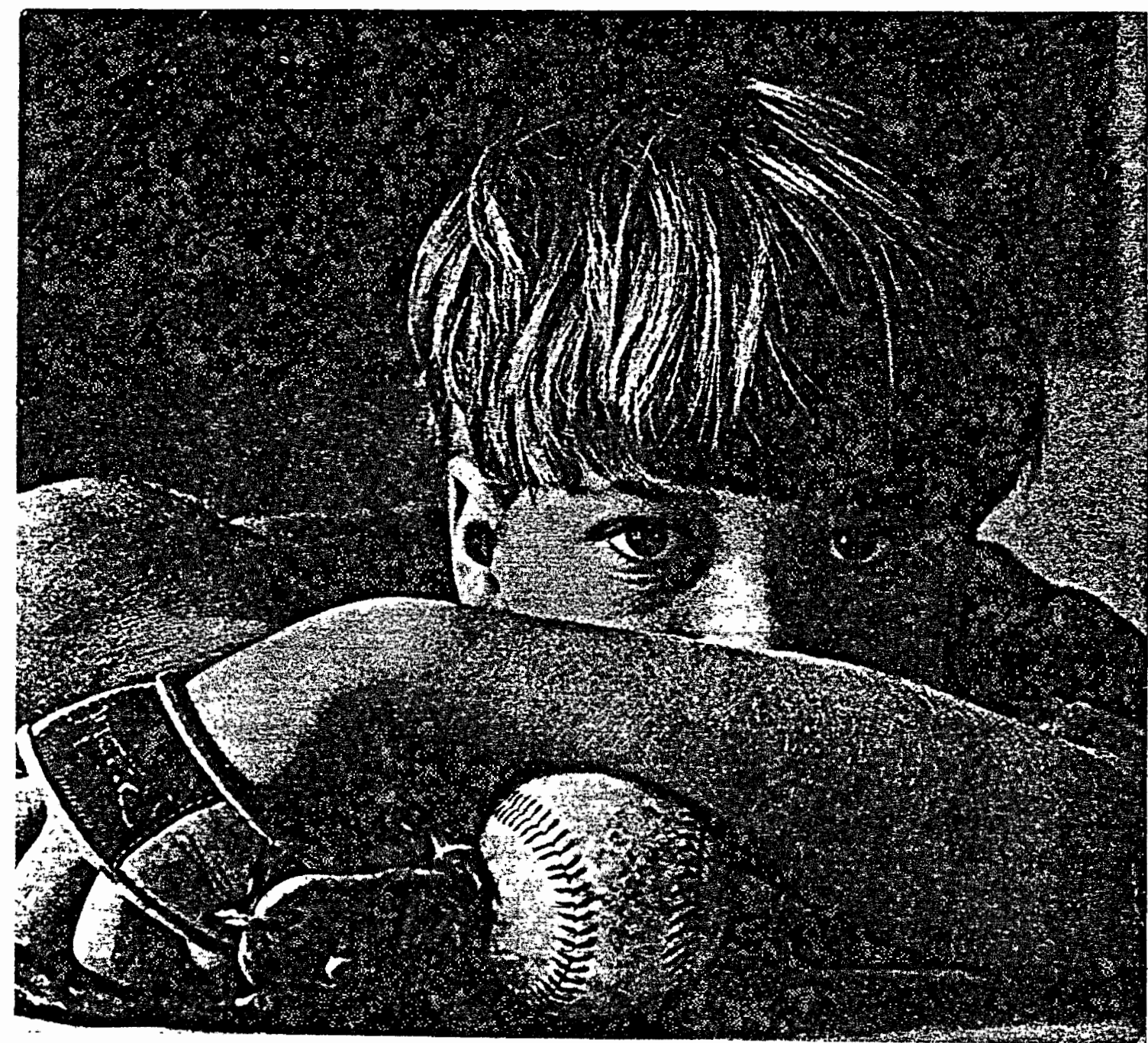

Picture No. 12 


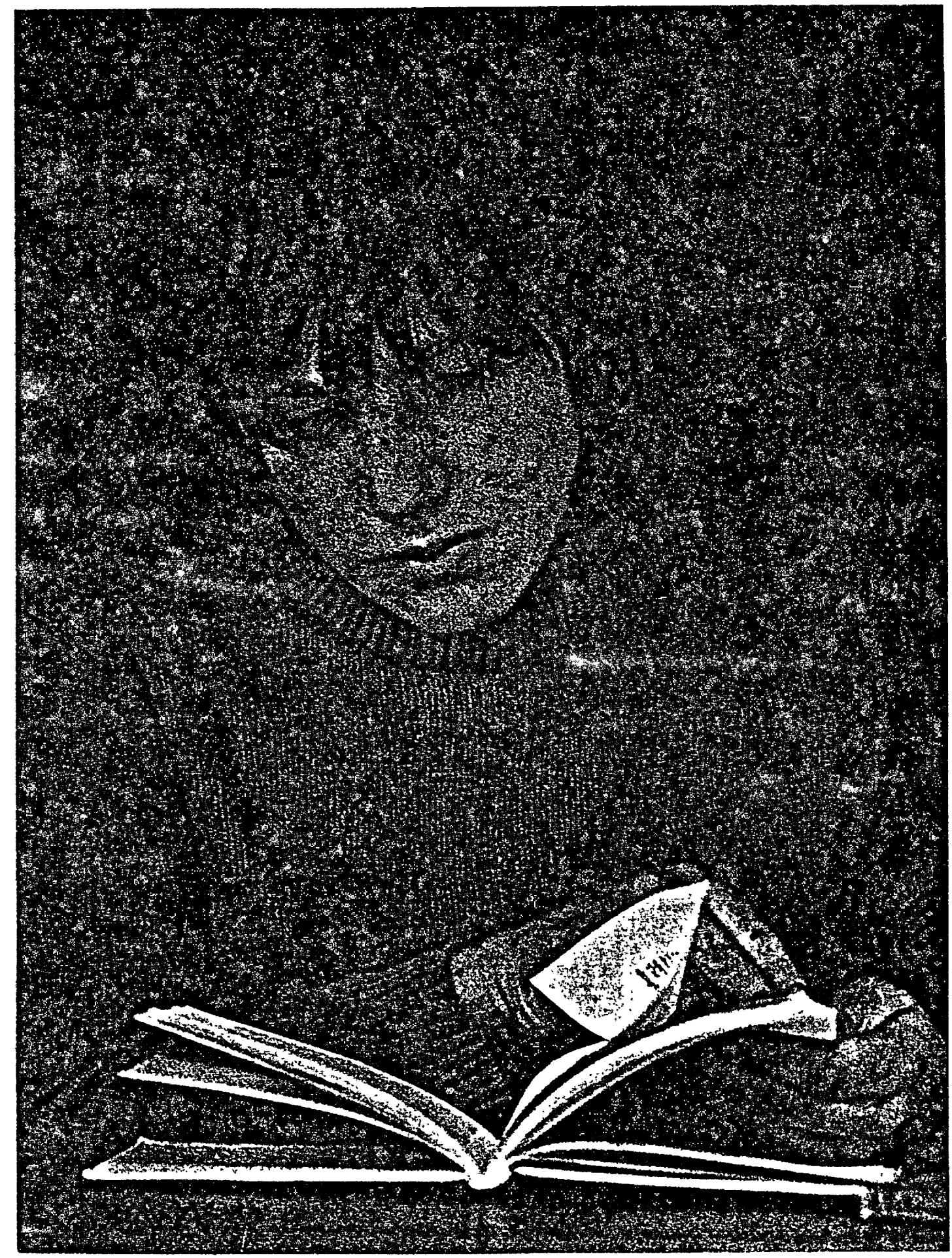

Picture No. 13 


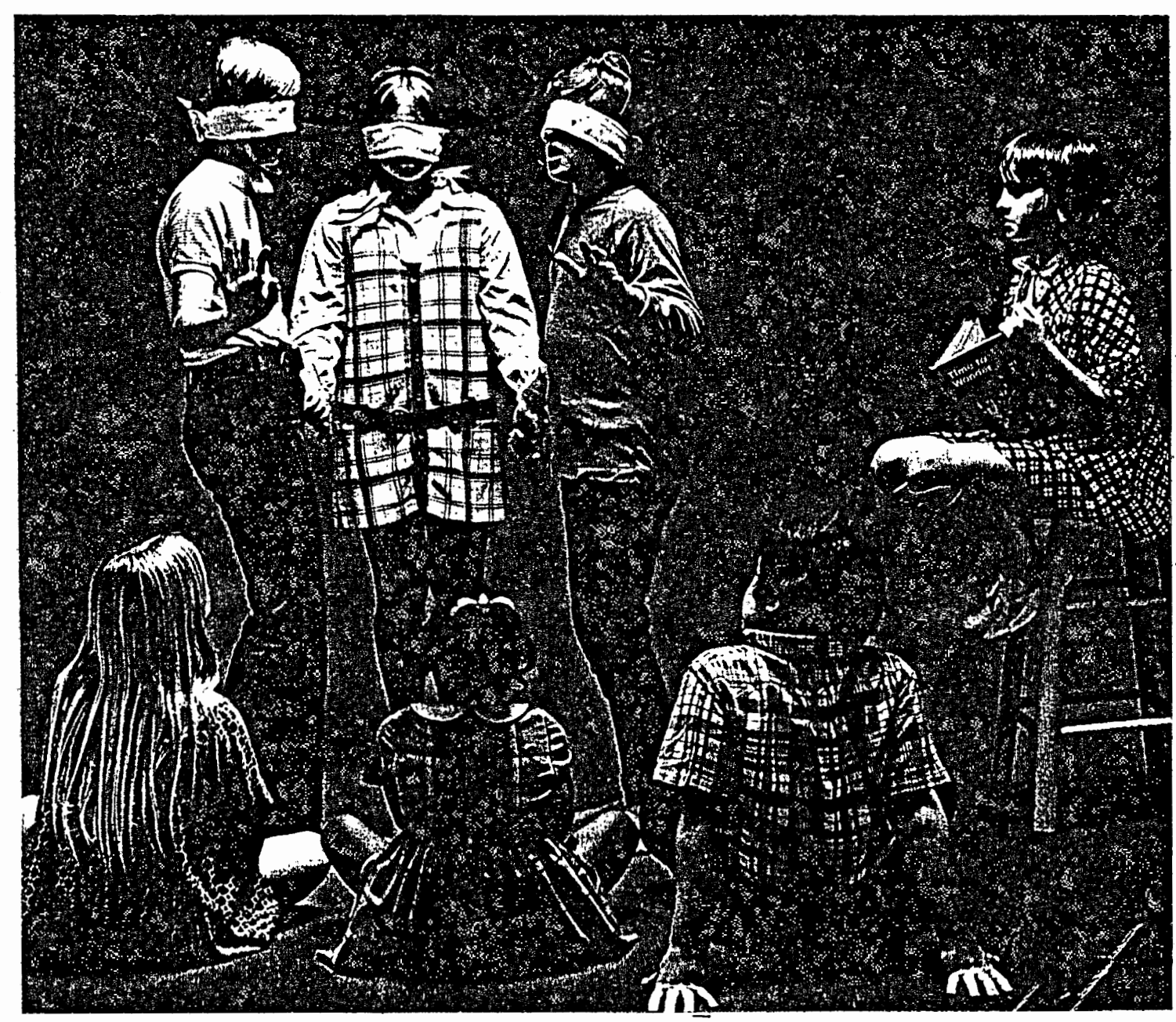

Picture No. 14 


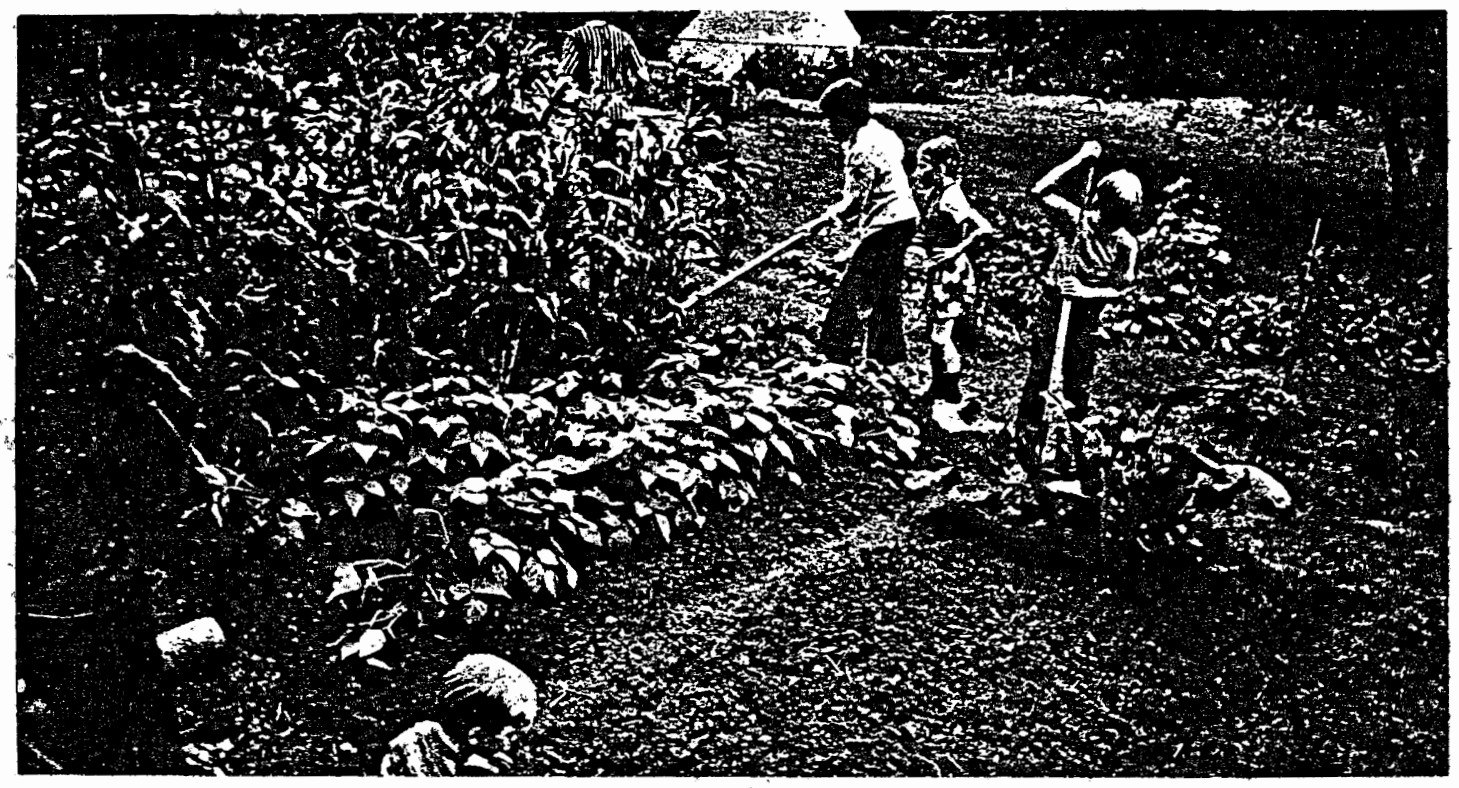

Picture No. 15 


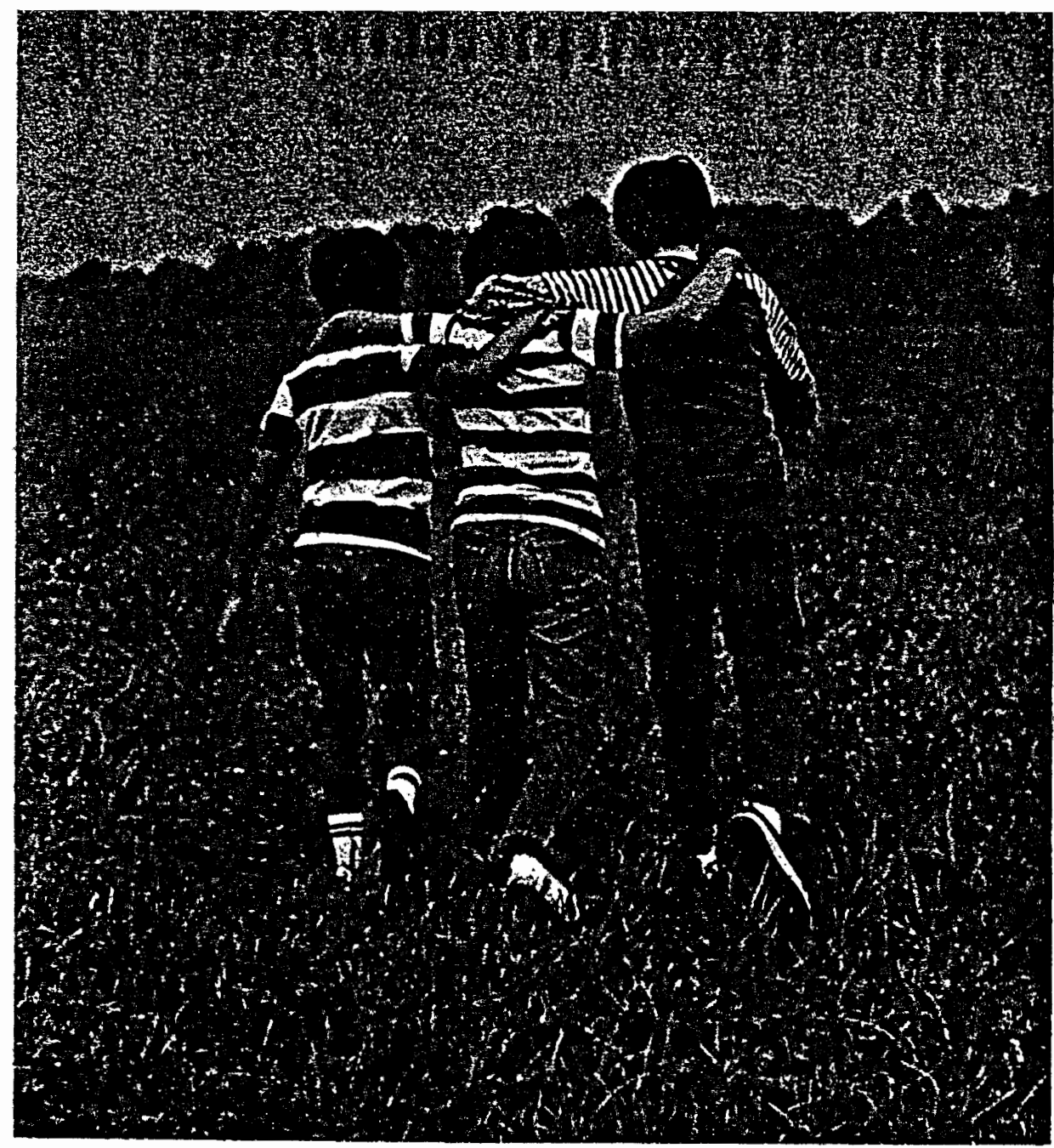

Picture No. 16 


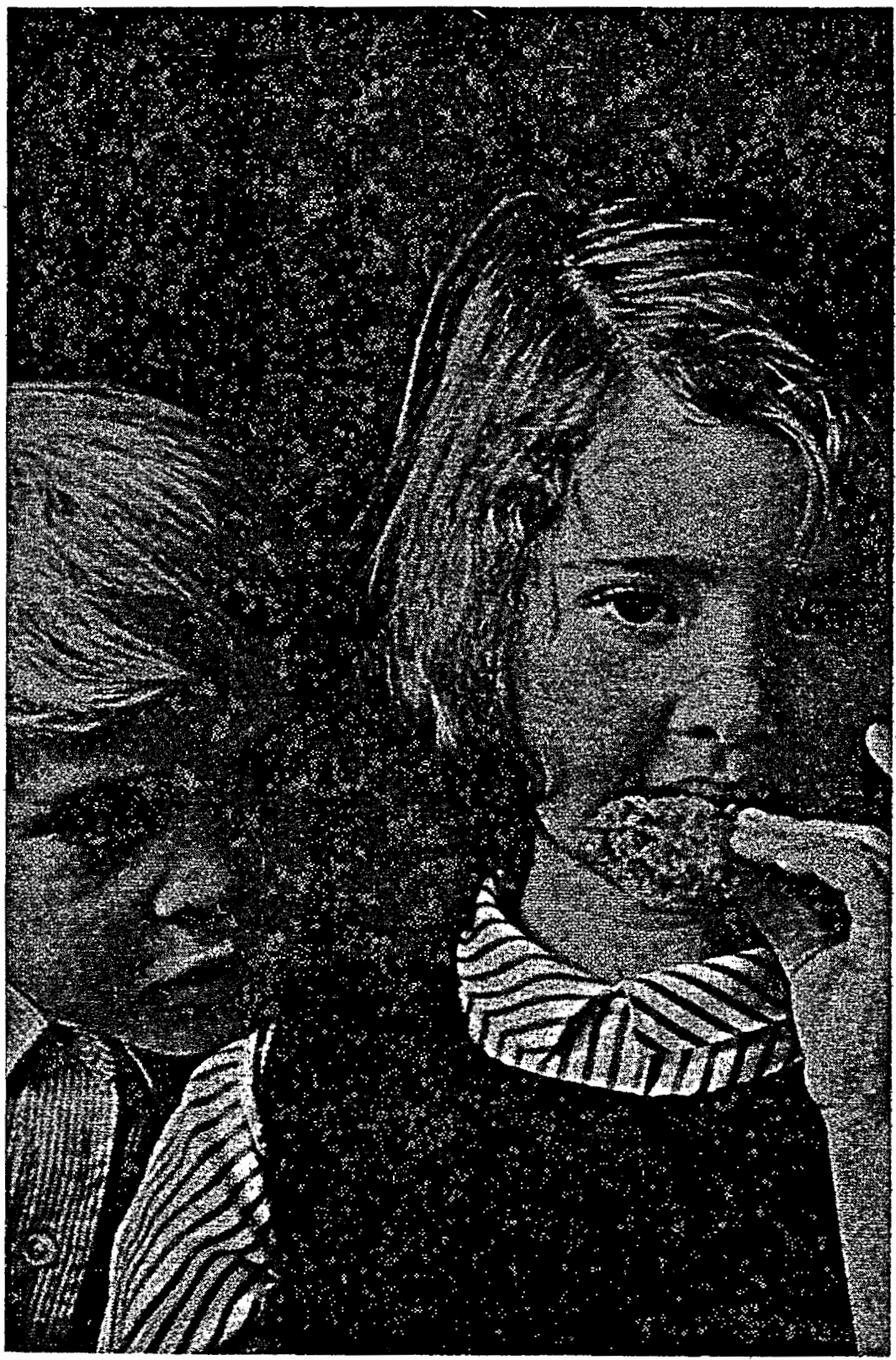

Picture No. 17 


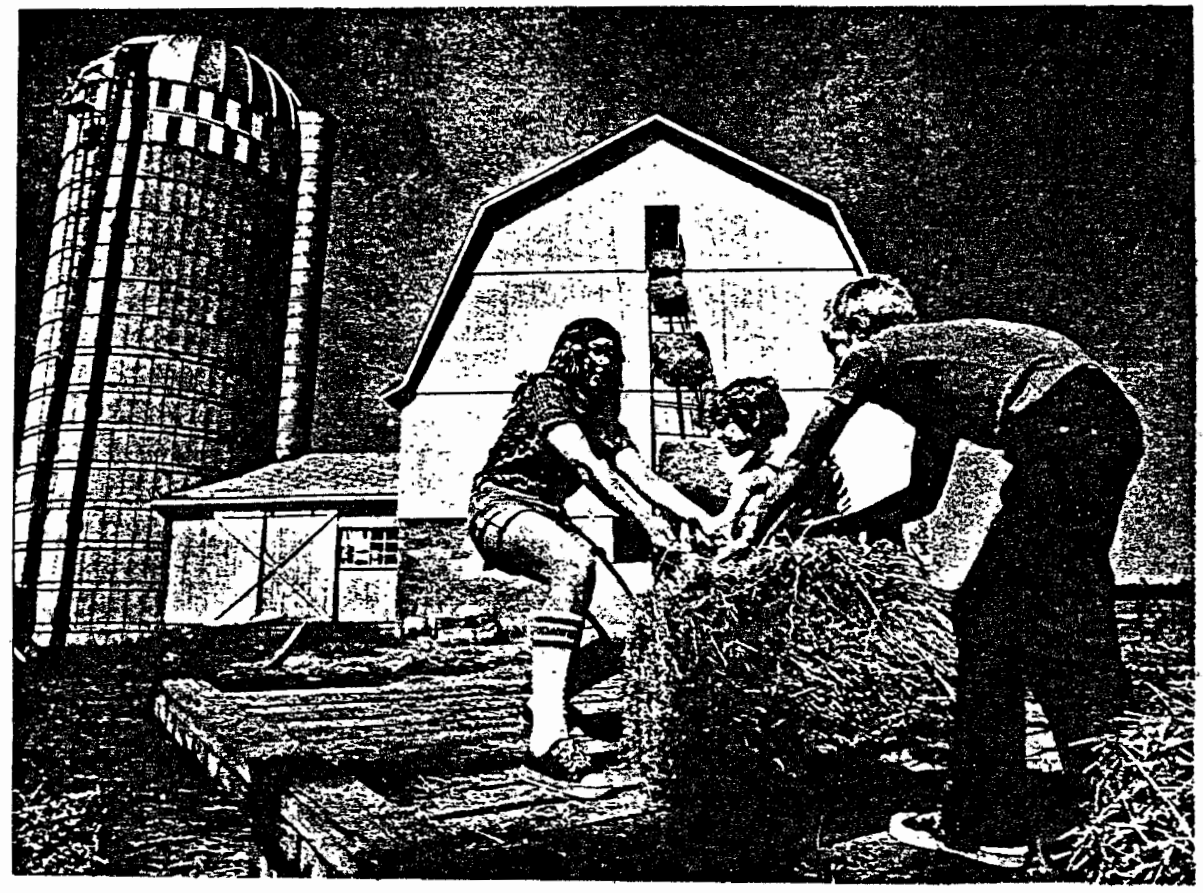

Picture No. 18 


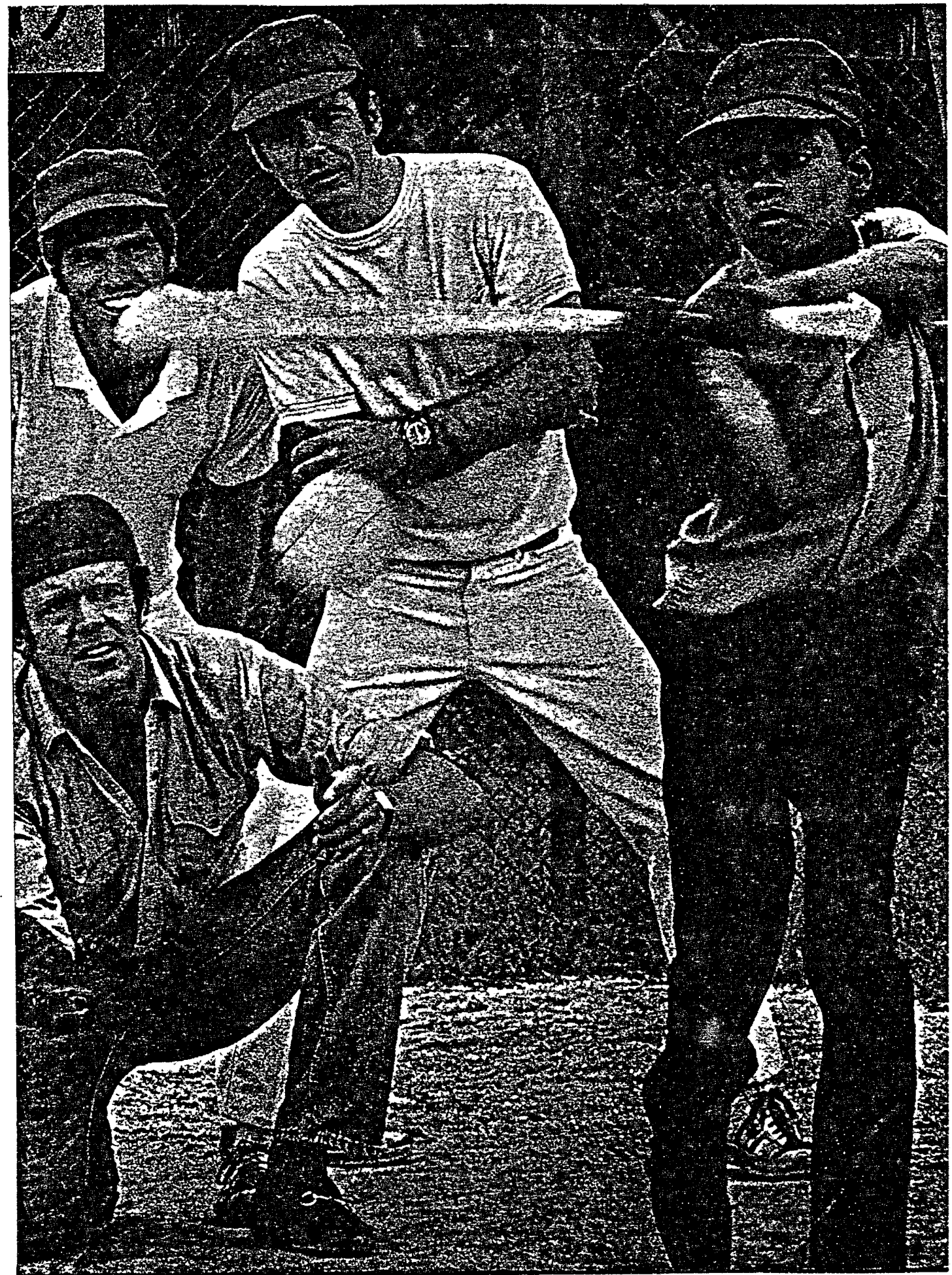

Picture No. 19 